This article was downloaded by: [b-on: Biblioteca do conhecimento online IPV]

On: 12 November 2013, At: 09: 36

Publisher: Routledge

Informa Ltd Registered in England and Wales Registered Number: 1072954 Registered office: Mortimer House, 37-41 Mortimer Street, London W1T 3J H, UK

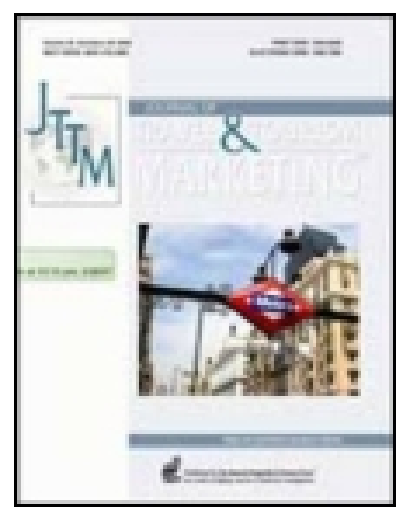

J ournal of Travel \& Tourism Marketing

Publication details, including instructions for authors and subscription information: http:// www.tandfonline.com/loi/ wttm20

\title{
Online travel purchasing: A literature review
}

Suzanne Amaro \& Paulo Duarte

Published online: 12 Nov 2013.

To cite this article: Suzanne Amaro \& Paulo Duarte (2013) Online travel purchasing: A literature review, Journal of Travel \& Tourism Marketing, 30:8, 755-785

To link to this article: http:// dx.doi.org/ 10.1080/ 10548408.2013.835227

\section{PLEASE SCROLL DOWN FOR ARTICLE}

Taylor \& Francis makes every effort to ensure the accuracy of all the information (the "Content") contained in the publications on our platform. However, Taylor \& Francis, our agents, and our licensors make no representations or warranties whatsoever as to the accuracy, completeness, or suitability for any purpose of the Content. Any opinions and views expressed in this publication are the opinions and views of the authors, and are not the views of or endorsed by Taylor \& Francis. The accuracy of the Content should not be relied upon and should be independently verified with primary sources of information. Taylor and Francis shall not be liable for any losses, actions, claims, proceedings, demands, costs, expenses, damages, and other liabilities whatsoever or howsoever caused arising directly or indirectly in connection with, in relation to or arising out of the use of the Content.

This article may be used for research, teaching, and private study purposes. Any substantial or systematic reproduction, redistribution, reselling, loan, sub-licensing, systematic supply, or distribution in any form to anyone is expressly forbidden. Terms \& Conditions of access and use can be found at http:// www.tandfonline.com/page/terms-and-conditions 


\title{
ONLINE TRAVEL PURCHASING: A LITERATURE REVIEW
}

\author{
Suzanne Amaro \\ Paulo Duarte
}

\begin{abstract}
Over the past two decades, there has been an increasing focus on the development of Information and Communication Technologies (ICTs), as well as the impact that they have had on the tourism industry and on travelers' behaviors. However, research on what drives consumers to purchase travel online has typically been fragmented. In order to better understand consumers' behavior toward online travel purchasing, this article offers a review of articles that were published in leading tourism and hospitality journals, the ENTER proceedings, and several articles from other peer-reviewed journals, found on the main academic search databases. The antecedents of online travel shopping found are classified into three main categories: Consumer Characteristics, Perceived Channel Characteristics, and Website and Product Characteristics. Finally, this study identifies several gaps and provides some orientation for future research.
\end{abstract}

KEYWORDS. Consumer behavior online, online travel shopping, online travel purchase intentions, review, tourism and hospitality

\section{INTRODUCTION}

The development of Information and Communication Technologies (ICTs) and particularly the Internet has had a profound impact on the travel industry (Buhalis \& Law, 2008; Kamarulzaman, 2007). These developments have changed travelers' behavior (Buhalis \& Law, 2008; Hung, Yang, Yang, \& Chuang, 2011) that now depend on the Internet to search for information, plan their travel, and purchase (Jeong \& Choi, 2005). Over a decade ago, Werthner and Klein (1999) had already stressed that tourism and ICTs fit well together since travel products and services have the ideal characteristics to be sold online (Lewis, Semeijn, \& Talalayevsky, 1998). Predictions that the Internet would have an enormous impact on how hospitality and tourism services are distributed are certainly proved true (Buhalis, 1998; Marcussen, 1999; Werthner \& Klein, 1999). Different sources evidence the importance of online travel shopping. For instance, in a survey lead by Nielsen (2008), travel was the most important online transaction category. According to the Danish Centre for Regional and Tourism Research (http://www.crt.dk), online travel sales increased by $17 \%$ from 2007 to 2008 and reached 58.4 billion Euros in the European market in 2008. Forty percent of

Suzanne Amaro is with the School of Technology and Management at the Polytechnic Campus Repeses in Viseu, Portugal.

Paulo Duarte is with NECE-Research Unit in Business Sciences of the Human and Social Sciences Faculty at the University of Beira Interior in Covilhã, Portugal (E-mail: pduarte@ubi.pt).

Address correspondence to: Suzanne Amaro, Escola Superior de Tecnologia e Gestão de Viseu, Campus Politécnico de Repeses, 3504-510 Viseu, Portugal. E-mail: samaro@ dgest.estv.ipv.pt 
Americans and $30 \%$ of Europeans book travel online. Despite the $20 \%$ in Asia, it is expected that this percentage will rise to about 30 or $40 \%$ over the next few years (Leggatt, 2011). While in 1998, airline companies did not sell more than $1 \%$ of their tickets online (Marcussen, 1999), this figure rose to a worldwide $26 \%$ by 2008, and to more than $50 \%$ in North America (SITA, 2008). Due to this, the future of online travel shopping looks promising. In fact, PhoCusWright, one of the leading travel industry research firms, predicts that by the end of 2012 travelers will book one third of the world's travel sales online (Travel Pulse, 2011).

Given the importance of online travel shopping, it is fundamental to examine which factors influence consumers to purchase online (Brown, Muchira, \& Gottlieb, 2007; Kah, Vogt, \& Mackay, 2008). Notwithstanding the growing body of literature in this field, the existent research is fragmented and has contradictory results. In view of the importance of online travel shopping, this article makes two valuable contributions to the body of knowledge. First, it provides researchers with a comprehensive synthesis of the extant studies related to this topic. Second, as it identifies the main gaps, it provides academics with directions for future research in this area.

The remainder of the article is organized as follows: the next section outlines the methodology used to conduct the literature review; the results from the literature review and the categorization of the variables affecting online travel shopping are then presented; following is a section where research gaps are identified and some guidelines for future research are suggested; and finally, the last section summarizes this study and indicates some limitations.

\section{METHODOLOGY}

For the purposes of this study, only fulllength peer-reviewed articles that established a relationship with intentions to purchase travel online $^{1}$ or actual usage of the Internet as a purchase mode were selected. Another criterion that articles had to meet was that they needed to address the purchase of travel online in general opposed to the purchase of travel on a specific travel website. Articles examining, for example, the effect of website quality on intentions to purchase on a specific website (e.g., Bai, $\mathrm{Hu}$, Elsworth, \& Countryman, 2004), the importance of value-added services on online travel websites (e.g., Lexhagen, 2005), or the evolution of online travel purchase behaviors in generational cohorts (e.g., Beldona, Nusair, \& Demicco, 2009) were discarded.

A structured approach based on Webster and Watson's (2002) recommendations was followed to conduct the literature review. These authors recommend examining leading journals and conference proceedings with a reputation for quality in order to find relevant articles since they are more likely to have the major contributions. Furthermore, to guarantee that other relevant articles from peer-reviewed journals were not excluded from this review, online databases for academic journals were also used. Using online databases to search for suitable articles for a literature review is a procedure that has been conducted by other well-known authors (e.g., Buhalis \& Law, 2008; Ip, Law, \& Lee, 2011).

Identifying the leading journals in the Tourism and Hospitality field was a challenging task. Arendt, Ravichandran, and Brown (2007) indicated that there were 57 tourism and hospitality related journals. Several academics suggest there are more than 100 (Ma \& Law, 2009; McKercher, Law, \& Lam, 2006). Nevertheless, a standard list of ranked tourism journals accepted by all universities and researchers does not exist (Law, 2010; McKercher et al., 2006). More recently, ever since several hospitality, leisure, sports, and tourism related journals were included in the Thomson Reuters Social Sciences Citation Index (SSCI), impact factors have also been used to evaluate journals. However, many authors argue that impact factors should not be used to evaluate research (Jamal, Smith, \& Watson, 2008; Seglen, 1997). The leading journals included in this study were the top 10 selected from four tourism and hospitality journal rankings listed in the studies of Pechlaner, Zehrer, Matzler, and Abfalter (2004), Ryan (2005), McKercher et al. (2006), 
TABLE 1. Rankings of Hospitality and Tourism Journals

\begin{tabular}{|c|c|c|c|c|c|c|}
\hline \multirow[t]{2}{*}{$\begin{array}{l}\text { Journals (in alphabetic order of journal } \\
\text { names) }\end{array}$} & \multicolumn{2}{|c|}{$\begin{array}{l}\text { Pechlaner et al. } \\
\qquad(2004)\end{array}$} & \multirow[t]{2}{*}{$\begin{array}{l}\text { Ryan } \\
(2005)\end{array}$} & \multirow[t]{2}{*}{$\begin{array}{l}\text { McKercher } \\
\text { et al. (2006) }\end{array}$} & \multirow[t]{2}{*}{$\begin{array}{l}\text { Murphy and } \\
\text { Law (2008) }\end{array}$} & \multirow{2}{*}{$\begin{array}{c}\text { SSCI 2-Year } \\
\text { impact factor } \\
(2010)\end{array}$} \\
\hline & USA & $\begin{array}{l}\text { Other } \\
\text { countries }\end{array}$ & & & & \\
\hline Annals of Tourism Research & 2 & 1 & 1 & 1 & 1 & 2 \\
\hline Asia Pacific Journal of Tourism Research & 16 & 19 & - & 8 & - & - \\
\hline British Food Journal & - & - & - & - & 5 & - \\
\hline Cornell Quarterly & 3 & 9 & 23 & - & 2 & 14 \\
\hline Current Issues in Tourism & - & - & - & - & - & 15 \\
\hline $\begin{array}{l}\text { International Journal of Contemporary } \\
\text { Hospitality Management }\end{array}$ & 13 & 18 & - & - & 6 & - \\
\hline $\begin{array}{l}\text { International Journal of Hospitality } \\
\text { Management }\end{array}$ & 8 & 7 & - & - & 11 & 5 \\
\hline International Journal of Tourism Research & - & - & 17 & 6 & 18 & 9 \\
\hline Journal of Gambling Studies & - & - & - & - & 9 & - \\
\hline Journal of Hospitality \& Tourism Research & 7 & 8 & - & - & 12 & 10 \\
\hline Journal of Leisure Research & 5 & 14 & 6 & - & - & 6 \\
\hline Journal of Sustainable Tourism & 11 & 4 & 4 & 4 & - & 4 \\
\hline Journal of Tourism Studies & 10 & 6 & 10 & 9 & - & - \\
\hline Journal of Travel and Tourism Marketing & 4 & 5 & 20 & 5 & 13 & 8 \\
\hline Journal of Travel Research & 1 & 3 & 3 & 3 & 4 & 3 \\
\hline Leisure Management & - & - & 7 & - & - & - \\
\hline Leisure Sciences & - & - & 8 & - & 10 & 7 \\
\hline Leisure Studies & - & - & 5 & - & 7 & 13 \\
\hline $\begin{array}{l}\text { Scandinavian Journal of Hospitality and } \\
\text { Tourism }\end{array}$ & - & - & - & - & - & 16 \\
\hline Therapeutic Recreation Journal & - & - & 9 & - & - & - \\
\hline Tourism Analysis & 9 & 10 & 14 & 7 & - & - \\
\hline Tourism Economics & 20 & 12 & 25 & 10 & 21 & 12 \\
\hline Tourism Geography & - & - & - & - & - & 11 \\
\hline Tourism Management & 6 & 2 & 2 & 2 & 3 & 1 \\
\hline
\end{tabular}

and Murphy and Law (2008; see Table 1). Moreover, the 2-year impact factors from SSCI were also considered to select leading journals. The 2010 SSCI list includes 33 journals from hospitality, leisure, sports, and tourism (ISI Web of Science, 2010). For the purpose of ranking, sports journals were eliminated. By selecting the top 10 rated journals from these studies and impact factors, a total of 24 journals were obtained. After carefully examining the aims and scope of these journals, nine were eliminated; some due to the fact that they were not related to the topic under review and others for not being peer-reviewed journals. The Journal of Hospitality and Tourism Technology, the Journal of Information Technology \& Tourism, and the annual proceedings of ENTER Conferences (organized by the International Federation for Information Technology and
Travel \& Tourism since 1994 and published in Information and Communication Technologies in Tourism), were added to the list of journals; this because they address two important domains relevant to the literature review: Information Communication Technologies (ICTs) and Tourism. A total of 17 research journals in hospitality and tourism and the ENTER conference proceedings were obtained for the purpose of this study (see Appendix).

In late 2011, the table of contents of the selected journals were analyzed. The articles addressing determinants of online travel purchase intentions or actual usage were then selected. Considering that the Internet became popular among the general public in 1995 (Marcussen, 1999), along with the fact that in the late 1990s airline companies and online travel agencies 
with booking functions (such as Expedia, Travelocity, Bookings, British Airways, Iberia, Finnair) were launched (Marcussen, 1999; Mitra, 2007; Microsoft, 1997), articles published between January 1995 and December 2011 were considered for the literature review.

As aforementioned, to guarantee that other relevant articles from peer-reviewed journals were not excluded from this literature review, the online databases for academic journals ScienceDirect (http://www.sciencedirect. com) and EBSCO (http://www.ebscohost.com), as well as Google Scholar (http://www.scholar. google.com) were used to search for suitable articles. These are considered to be the largest and most popular databases (Ip et al., 2011; Ryan, 2005). The keywords used for this search included different word combinations related to online travel shopping such as "travel shopping online," "travel e-commerce," and "e-travelers purchasing behavior."

\section{FINDINGS}

A total of 54 full-length articles were found relevant to the review. Table 2 presents the distribution of these articles, per journal and year.

After carefully reading each article, variables affecting online travel purchasing usage and intention were classified according to the antecedents of online shopping based on Chang, Cheung, and Lai's (2005) reference model (see Figure 1). This model is composed of three categories with subcategories. The three major categories are: (a) characteristics of the consumers, (b) perceived characteristics of the Internet as a sales channel, and (c) characteristics of the website or products. Minor adaptations were made to the subcategories of this framework to account for specific antecedents of online shopping in the travel context.

\section{Consumer Characteristics}

\section{Demographic Variables}

Consumer demographics are among the most frequently studied factors and were the focus of the first article addressing online travel shopping. In their seminal study, Weber and Roehl
(1999) found that there were no differences between online purchasers and nonpurchasers regarding gender and race. However, individuals between the ages of 25 to 55, possessing higher levels of education and income, were more likely to purchase travel online. Effectively, the majority of the succeeding studies also found that travelers with higher education levels were more likely to purchase travel online (Heung, 2003; Kamarulzaman, 2007, 2010; Kim \& Kim, 2004; Law \& Bai, 2008; Law, Leung, \& Wong, 2004; Lee, Qu, \& Kim, 2007; Li \& Buhalis, 2006; Morrison, Jing, O'Leary, \& Cai, 2001; Wolfe, Hsu, \& Kang, 2004), but not without some contradictory evidence (e.g., Weber \& Roehl, 1999). In fact, in Morrison et al.'s model (2001), education was found to be the only sociodemographic variable that affected the likelihood of using the Internet to purchase travel. Yet, other studies found that there was no relationship between them (Beldona, Racherla, \& Mundhra, 2011; Garín-Muñoz \& Pérez-Amaral, 2011; Li \& Buhalis, 2006; Moital, Vaughan, \& Edwards, 2009; Wolfe et al., 2004). Strangely, Chen (2006) found that consumers with higher education levels did not trust travel websites as much.

Online travel purchasers also seem to have higher levels of income (e.g., Card, Chen, \& Cole, 2003; Heung, 2003; Law \& Bai, 2008; Law et al., 2004) and are generally younger (e.g., Kamarulzaman, 2007; Kim \& Kim, 2004; Wolfe et al., 2004) than those who purchase in traditional travel agencies. Once again there is no consensus on this subject matter. For example, Kim and Kim (2004) found that online purchasers and nonpurchasers did not differ according to level of income. On the contrary, Wolfe et al. (2004) actually claimed that travelers who used a travel agent were more likely to be in the upper income levels. Regarding China, Li and Buhalis (2006) found that there were no significant differences in income levels between lookers and bookers. Regarding age, there are also contradictory results. Wolfe et al. (2004) reported that younger consumers were more likely to purchase online, while Law and Bai (2008) noted the opposite. Other researchers (Moital, Vaughan, \& Edwards, 2009) concluded 


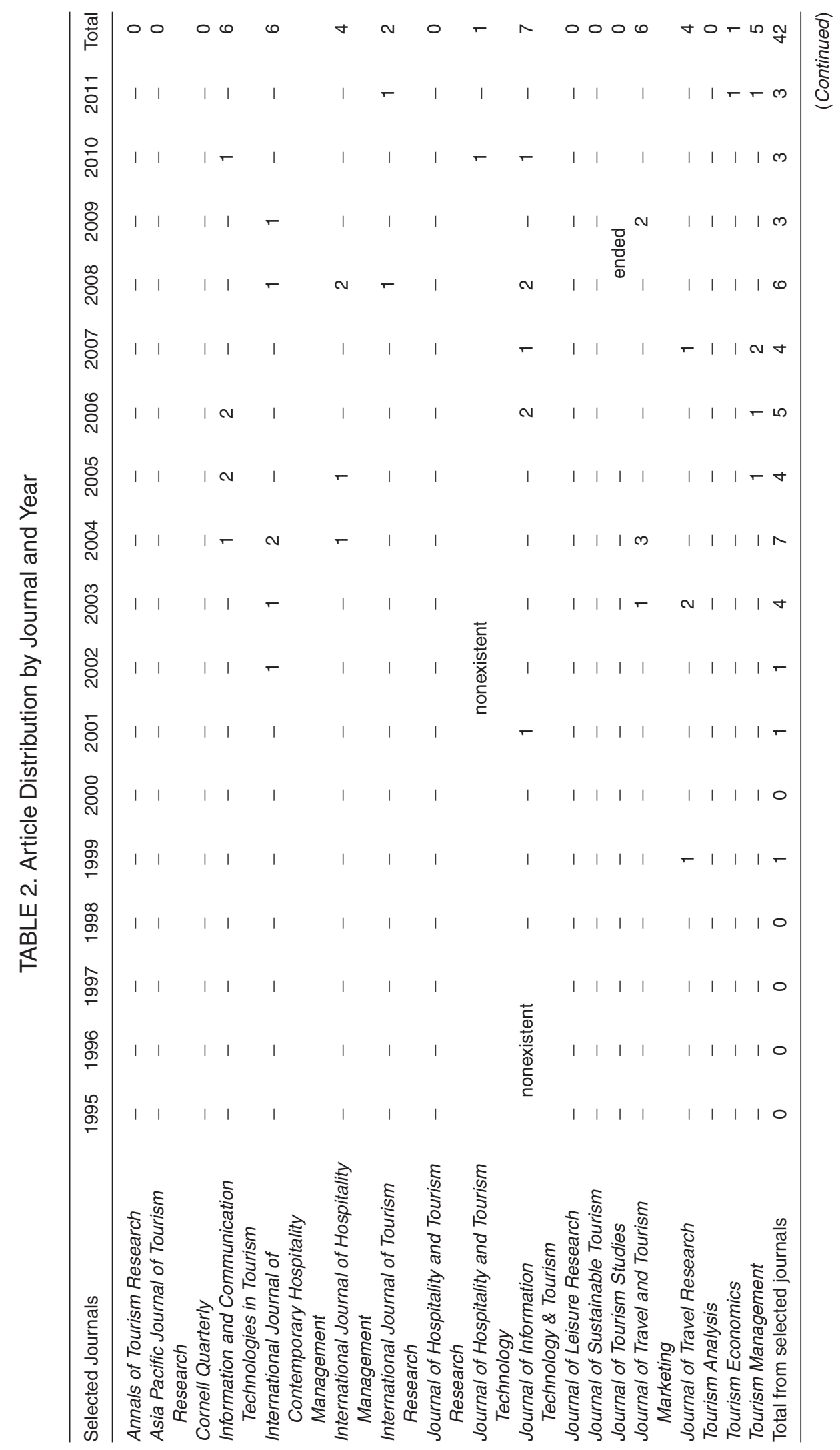




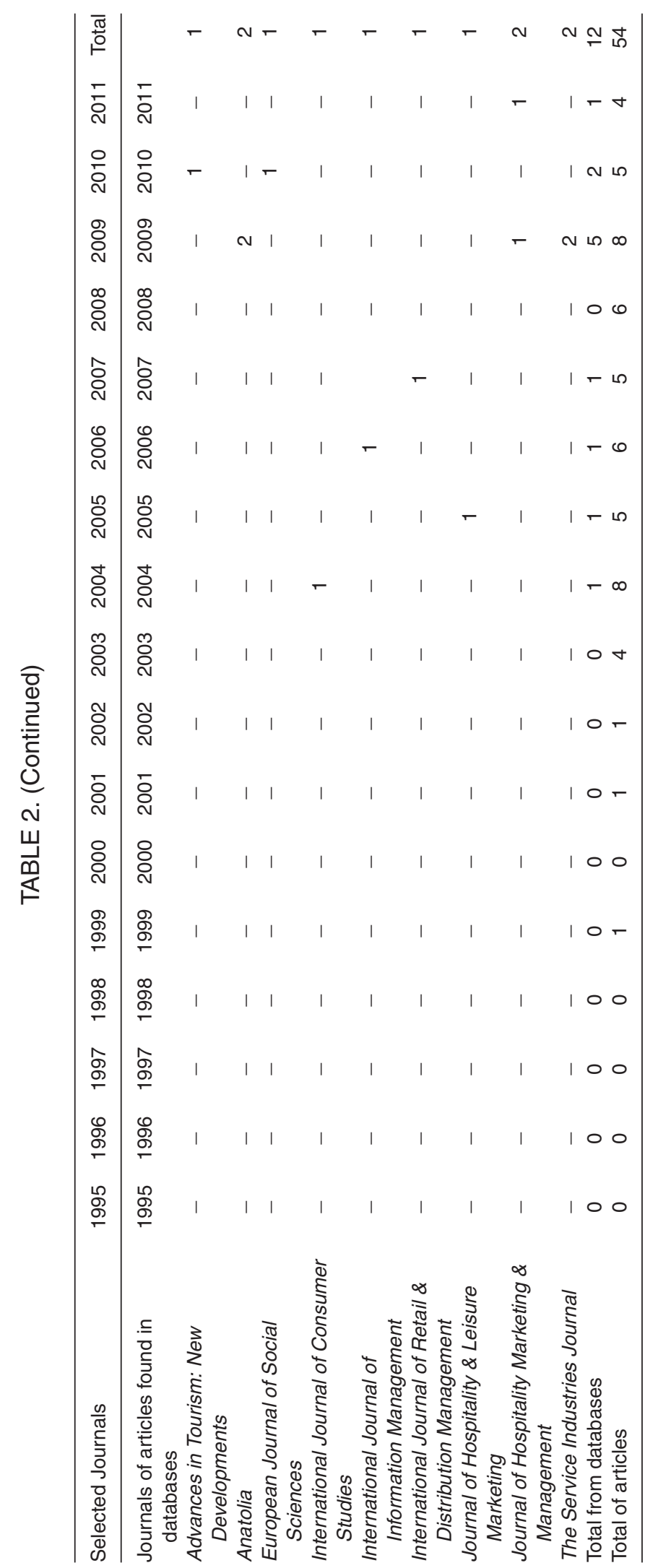


FIGURE 1. Antecedents of Online Shopping

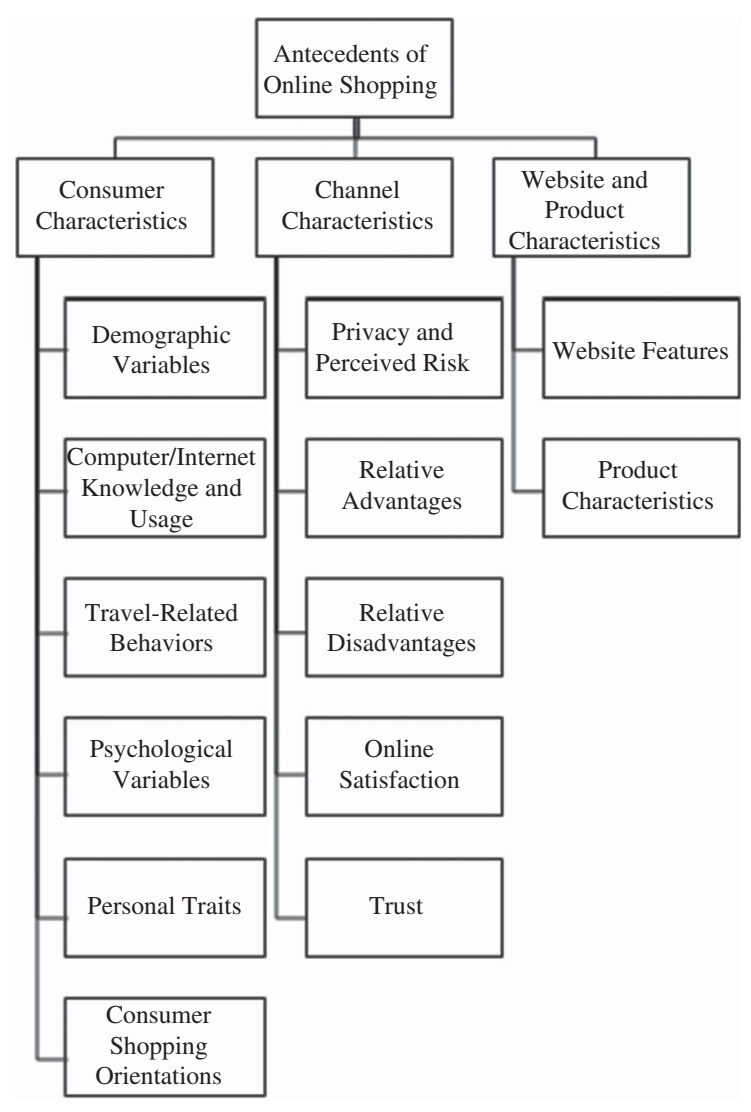

that age did not influence the probability of purchasing travel online.

These contradictory findings regarding demographic variables may be the result of a shift in the demographic profile of online travel purchasers. This is due to the fact that as the Internet becomes more widespread, online travel purchase has become more common in individuals with lower incomes and lower education levels. However, these differences may also be due to other factors such as different sampling methods or cultural differences. In either case there is a clear need to expand research in this area.

\section{Computer/Internet Knowledge and Usage}

Computer and Internet knowledge as well as usage are frequently and positively associated with online shopping predilection. Early studies have shown that consumers who purchase travel online were more likely to have more years of Internet experience (Card et al., 2003; Kah et al., 2008; Kamarulzaman, 2007, 2010; Kim \& Kim, 2004; Weber \& Roehl, 1999), spend more time online (Beldona et al., 2011; Kah et al., 2008; Kim \& Kim, 2004; Morrison et al., 2001; Weber \& Roehl, 1999), and have prior online shopping experience (Kim, Ma, \& Kim, 2006; Moital, Vaughan, Edwards, \& Peres, 2009).

Such findings are not surprising since it is necessary to have computer and Internet knowledge to purchase travel online. However, other studies have found that neither Internet experience (Jensen, 2009), frequency of Internet use (Garín-Muñoz \& Pérez-Amaral, 2011), computer usage (Moital, Vaughan, \& Edwards, 2009) or travelers' prior experience with online shopping (Jensen, 2009; Morosan \& Jeong, 2008) had an effect on intentions to purchase travel online or actual usage.

It is, however, important to note that early Internet adopters and individuals that use the Internet more frequently do have higher selfperceptions of technology use (Kah et al., 2008), also known as user's self-efficacy. This is positively associated with the probability of adopting online travel shopping (Li \& Buhalis, 2005, 2006). Having a positive attitude toward the Internet (e.g., "the Internet is as essential in my life as any other thing") seems to be a determinant to adopt online travel shopping (Ryan \& Rao, 2008). In fact, individuals that are apprehensive toward the use of the Internet are less likely to purchase or search for travel online (Susskind, Bonn, \& Dev, 2003) while consumers' with higher perceptions of Internet value are more likely to purchase travel online (Beldona et al., 2011).

The type of travel websites visited can also affect the probability of purchasing travel online. Li and Buhalis (2005) claim that those who often visit travel suppliers' websites (such as BritishAirways.com) are more likely to become bookers than those who often visit websites of online travel services (such as Travelocity.com). In contrast, Morrison et al. (2001) argued that those who visit websites of online travel services most often are more likely to purchase travel online. Similar to Morrison's findings, Kamarulzaman (2007, 2010) found that online travel purchasers prefer to purchase 
from online travel agents, since they provide all sorts of travel products to customers on the same website. For hotel bookings, Morosan and Jeong $(2006,2008)$ also found that users had a more favorable attitude and stronger intention to use third-party websites than hotel websites.

Park and Chung (2009) found that consumers who entered a travel website directly were more likely to make a purchase online than those that entered the site via a referring website. Furthermore, their study indicated that the longer the travel website visit length was, along with the fewer number of pages viewed, the more likely a consumer was to purchase online.

\section{Travel-Related Behaviors}

Researchers have found that certain travelrelated behaviors are linked to the purchase of travel online. For instance, several studies have found that travelers that search for travel information online are more likely to purchase travel online (Jensen, 2012; Kamarulzaman, 2007, 2010; Susskind \& Stefanone, 2010; Wen, 2010; Wolfe et al., 2004). Despite this being an expectable finding, Jensen (2012) found that this relationship was weak, reflecting that online travel search may not necessarily be followed by an online travel purchase. Furthermore, other studies were even more dramatic suggesting that there was no relationship between searching for travel information online and the intention to purchase travel online ( $\mathrm{Li} \&$ Buhalis, 2005, 2006; Powley, Cobanoglu, \& Cummings, 2004). In fact, Jun, Vogt, and MacKay (2007) reported that travelers were more likely to use the Internet for travel information search than for travel purchase.

Other travel-related behaviors have been explored to determine their effect on the likelihood of purchasing online. For instance, Morrison et al. (2001) acknowledged that people who had traveled to other countries in the past 12 months were more likely to purchase travel online, while several other studies have shown that individuals with higher levels of travel experience are more likely to purchase travel online (Jensen, 2012; Jun et al., 2007; Moital, Vaughan, \& Edwards, 2009; Wolfe et al., 2004).
In contrast, other studies found that the number of trips taken did not distinguish online purchasers from nonpurchasers (Li \& Buhalis, 2006) and that travel frequency was not related to the likelihood of purchasing airline tickets online (Beldona et al., 2011). Morrison et al. (2001) and Li and Buhalis (2005, 2006) interestingly found that having a membership in a frequent flyer program did not influence that probability of purchasing travel online. Another interesting variable that was only examined in one study was the purpose of the trip. Law et al. (2004) found that those whose purpose was traveling for business were more likely to purchase online, while those whose purpose was to visit relatives were less likely.

\section{Psychological Variables}

The psychological variables are variables derived from psychological theories such as the theory of reasoned action (TRA; Fishbein \& Ajzen, 1975) and the theory of planned behavior (TPB; Ajzen, 1991). The TRA suggests that a person's behavioral intention depends on the person's attitude about behavior and also by perceived social pressure to perform or not to perform the behavior, a social factor termed subjective norm (Ajzen, 1991). The TPB is actually an extension of the TRA, made to overcome the original model's limitations in dealing with behaviors over which people have incomplete volitional control. It adds a third determinant of behavioral intention: perceived behavioral control (Ajzen, 1991).

In the online travel context, studies have consistently found that attitude toward online shopping is a determinant of intention to purchase travel online (Bigné, Sanz, Ruiz, \& Aldás, 2010; Lee et al., 2007; Morosan \& Jeong, 2006, 2008). However, regarding subjective norm, the available empirical evidence is contradictory. Lee et al. (2007) found that referents' opinions (subjective norm) had an impact on travelers' intention to purchase online. Yet, San Martín and Herrero (2012), whose study contained similar hypotheses, evidenced that the social influence regarding the use of rural accommodation websites did not affect online purchase intentions. Morrison et al. (2001) also 
studied the influence of friends and others on the intention to purchase travel online, using a factor labeled "Communicability." They concluded that travelers are more likely to purchase travel online if they know that others are doing similarly. In contrast, Li and Buhalis (2006) asserted that communicability was not important in explaining the adoption of online travel shopping.

Another important psychological variable is perceived behavioral control (PBC) defined as "the perceived ease or difficulty of performing the behavior" (Ajzen, 1991, p. 188). Bigné et al. (2010) decomposed PBC into self-efficacy and facilitating conditions. Self-efficacy is related to perceived ability, while facilitating conditions are external resource constraints (Taylor \& Todd, 1995). Their results indicated that none of these dimensions influenced Spanish travelers' intention to purchase airline tickets online, but did influence their attitude, which then influenced intention. San Martín and Herrero (2012) also found that facilitating conditions did not affect intentions to purchase online.

PBC is a concept similar to self-efficacy (Ajzen, 1991, 2002) that in the online shopping context is defined as "a consumer's selfassessment of his/her capabilities to shop online" (Vijayasarathy, 2004, p. 751). Li and Buhalis $(2005,2006)$ used the self-efficacy dimension and found that Chinese online travel purchasers had a higher degree of self-efficacy than lookers, indicating a positive relationship between self-efficacy and online travel purchases.

\section{Personal Traits}

Despite being commonly accepted that personal traits influence online purchasing behavior, few studies have addressed personal traits as determinants of online travel shopping. Indeed, only three personal characteristics were found in the studies addressing online travel shopping: innovativeness, opinion leadership, and involvement.

Innovativeness was the personal characteristic that most researchers examined. Evidence was found to support that consumers' innovativeness has a positive relationship with online travel shopping adoption (Kamarulzaman, 2007; Li \& Buhalis, 2005, 2006), and moderates the effect between travelers' attitude and their intention to purchase travel online (Lee et al., 2007). In fact, online travel purchasers are more likely to be high-tech prone (Card et al., 2003), are more receptive to new technological innovations (Kim et al., 2006), and like trying new technologies (Heung, 2003).

Opinion leadership, defined as the degree to which an individual is able to influence other individuals' attitudes or behavior (Rogers, 1995), was examined in two studies with contradictory results. Card et al. (2003) reported that online travel purchasers had higher scores on opinion leadership than nonpurchasers. On the other hand, Kamarulzaman's (2007) results indicated that there was not a significant relationship between opinion leadership and the adoption of online travel shopping. Kamarulzaman (2007) argues that in spite of this insignificant relationship, marketers should not ignore the role of opinion leaders in influencing Internet users' decisions to adopt online travel shopping.

Involvement was another personal characteristic considered in Kamarulzaman's (2007) study. Although there does not exist a commonly accepted definition of involvement, broad definitions of involvement-such as Rothschild's (1984) as "a state of motivation, arousal, or interest" (p. 217) — paved the way for the concept to be applied in multiple contexts. Kamarulzaman (2007) found that there was a direct effect between consumers' involvement with online shopping and online travel purchasing. Two different studies conducted at a later time (Moital, Vaughan, \& Edwards, 2009; Moital, Vaughan, Edwards, et al., 2009) reached identical conclusions. Therefore, retailers need to get consumers more involved with online purchasing in order to increase online travel purchasing (Kamarulzaman, 2007; Moital, Vaughan, Edwards, et al., 2009).

\section{Consumer Shopping Orientations}

A topic that has received little attention is the relationship between shopping orientations 
and online travel shopping. Shopping orientations refer to general predispositions toward the act of shopping (Gehrt \& Carter, 1992) and can be applied to the online context. In an earlier study, Jensen (2009) investigated if two shopping orientations, time-saving orientation and store-enjoyment orientation, had an effect on intentions to purchase travel online. The study concluded that a direct relationship did not exist. However, travelers' shopping orientation affected their perceived motivators and barriers to purchase online which in turn affected intentions. For example, travelers that are time-saving oriented tend to value convenience that was found to influence intentions to purchase travel online. In a later study, using price-saving orientation, time-saving orientation, information orientation, personalized orientation, and store-enjoyment orientation, Jensen (2012) found that the only shopping orientation that had a direct effect on online travel purchasing was store-enjoyment orientation. Indeed, the results revealed that storeenjoyment oriented consumers were less likely to purchase travel products online. In a similar vein, Kolsaker, Lee-Kelley, and Choy (2004) argued that one of the reasons why Hong Kong consumers appear to be reluctant to purchasing airline tickets online is due to the fact that they enjoy shopping and view it as a social activity. Jensen (2012) suggests that online retailers need to improve travelers' perceived enjoyment of visiting online travel stores to attract travelers to purchase online. The effects of consumer characteristics on intentions to purchase travel online and actual purchases of travel online are summarized in Table 3.

\section{Perceived Channel Characteristics}

\section{Privacy and Perceived Risk}

In the travel and tourism context, risk issues play a significant role in inhibiting purchase of travel online. This can be observed in Kolsaker et al.'s (2004) study on why Hong Kong consumers seem reluctant to purchase airline tickets online even though Hong Kong is among the countries with the highest broadband penetration and Internet access. Their findings revealed that Hong Kong consumers recognized that it was convenient to purchase airline tickets online, but the risk involved in the purchase outweighed the convenience. Using the same product, Kim, Kim, and Leong (2005) have also investigated the effect of perceived risk on the intention to purchase airline tickets online. In their study, perceived risk was considered a multidimensional construct, consisting of seven types of risk: performance risk, financial risk, physical risk, psychological risk, social risk, time risk, and security risk. The authors found that all seven risk dimensions were negatively correlated with consumers' purchase intentions.

Using the same seven dimensions of perceived risk, but this time in the United States, Kim, Qu, and Kim (2009) found the expectedi.e., nonpurchasers perceived a higher risk on financial, performance, psychological, security, and time risks than online purchasers of airline tickets. Considering not just airline tickets but all types of travel services, Jensen (2012) realized that perceived risk was negatively related to consumers' intention to purchase travel online. This relationship between perceived risk and online travel purchases also seems to be consistent across studies conducted worldwide. For instance, in Spain, Bigné et al. (2010) noticed that Spanish Internet users who did not buy airline tickets online were essentially concerned with three risk dimensions: performance, psychological, and privacy.

Privacy concerns are often pointed out as one of the main reasons consumers do not make online purchases (George, 2004). However, Brown, Muchira, and Gottlieba (2005, 2007) studied the effects of privacy on online travel purchase behavior and unexpectedly found that although privacy issues concerned consumers, they did not have an impact on their actual or intended online travel purchase. The authors argued that these results may be due to the young age of their sample, as younger groups tend to have lower privacy concerns than older ones. These findings could also be the result of the increasing trust and security in computer systems as asserted by Bogdanovych, Berger, Simoff, and Sierra (2006). 


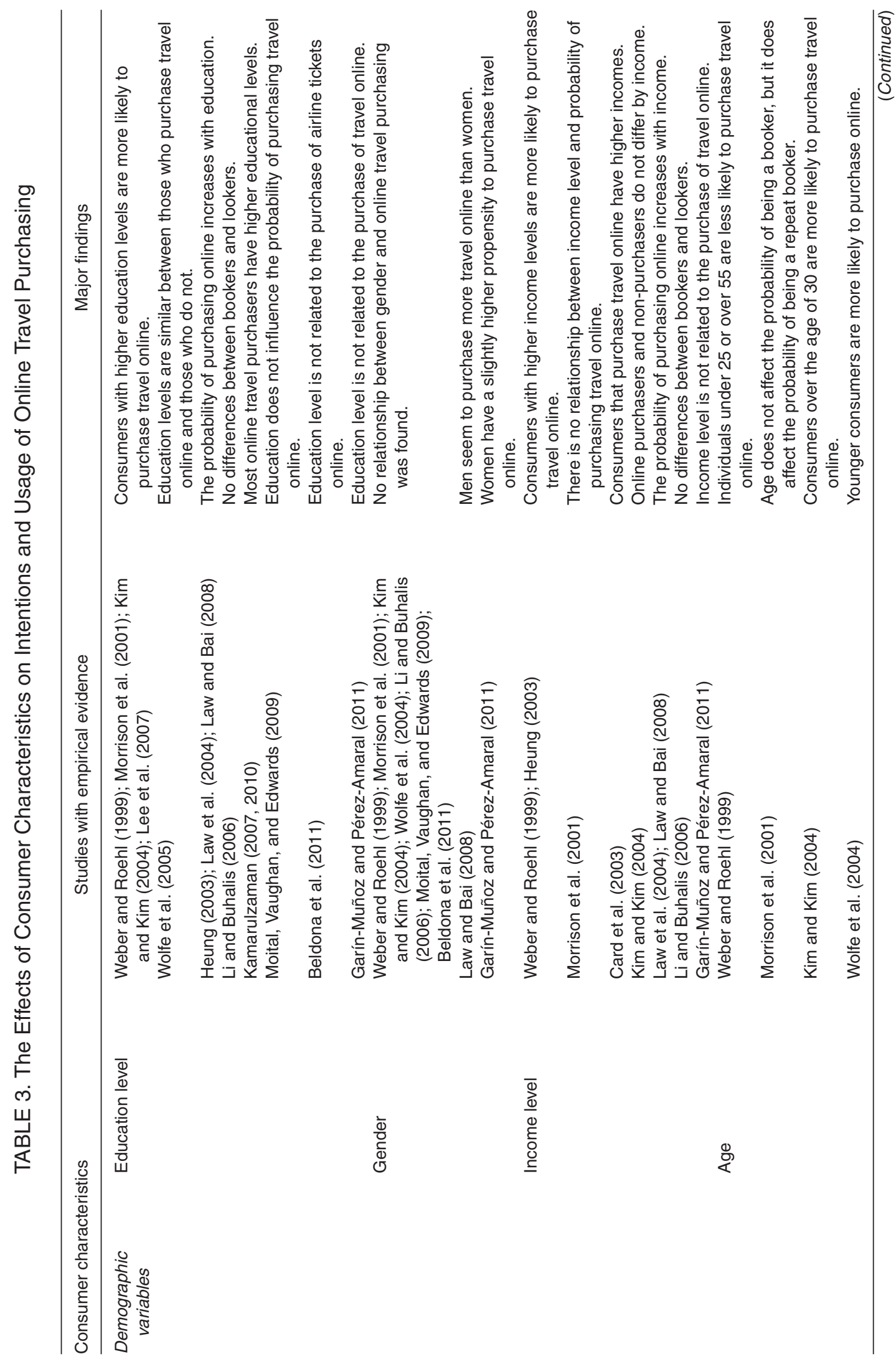




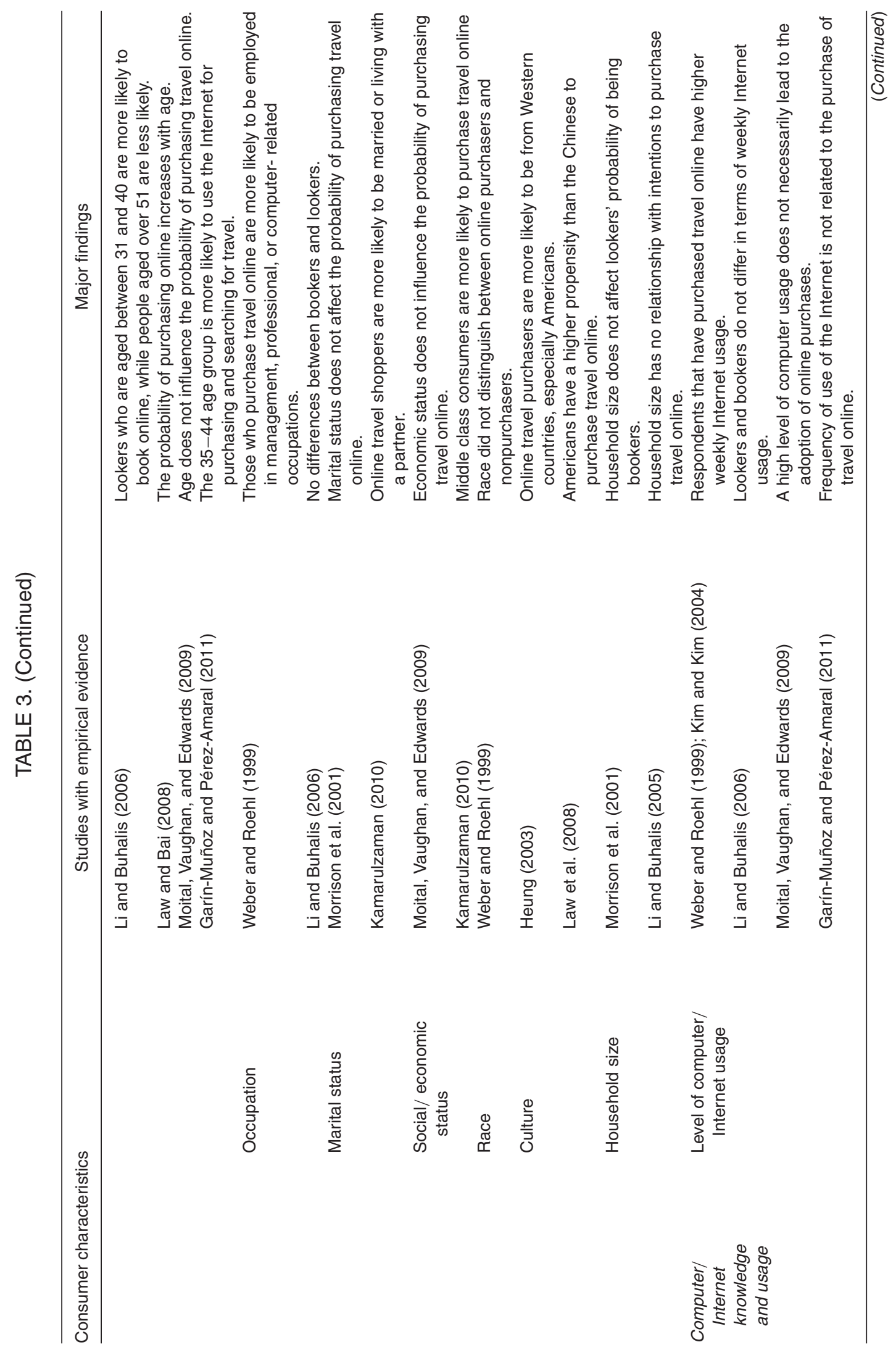




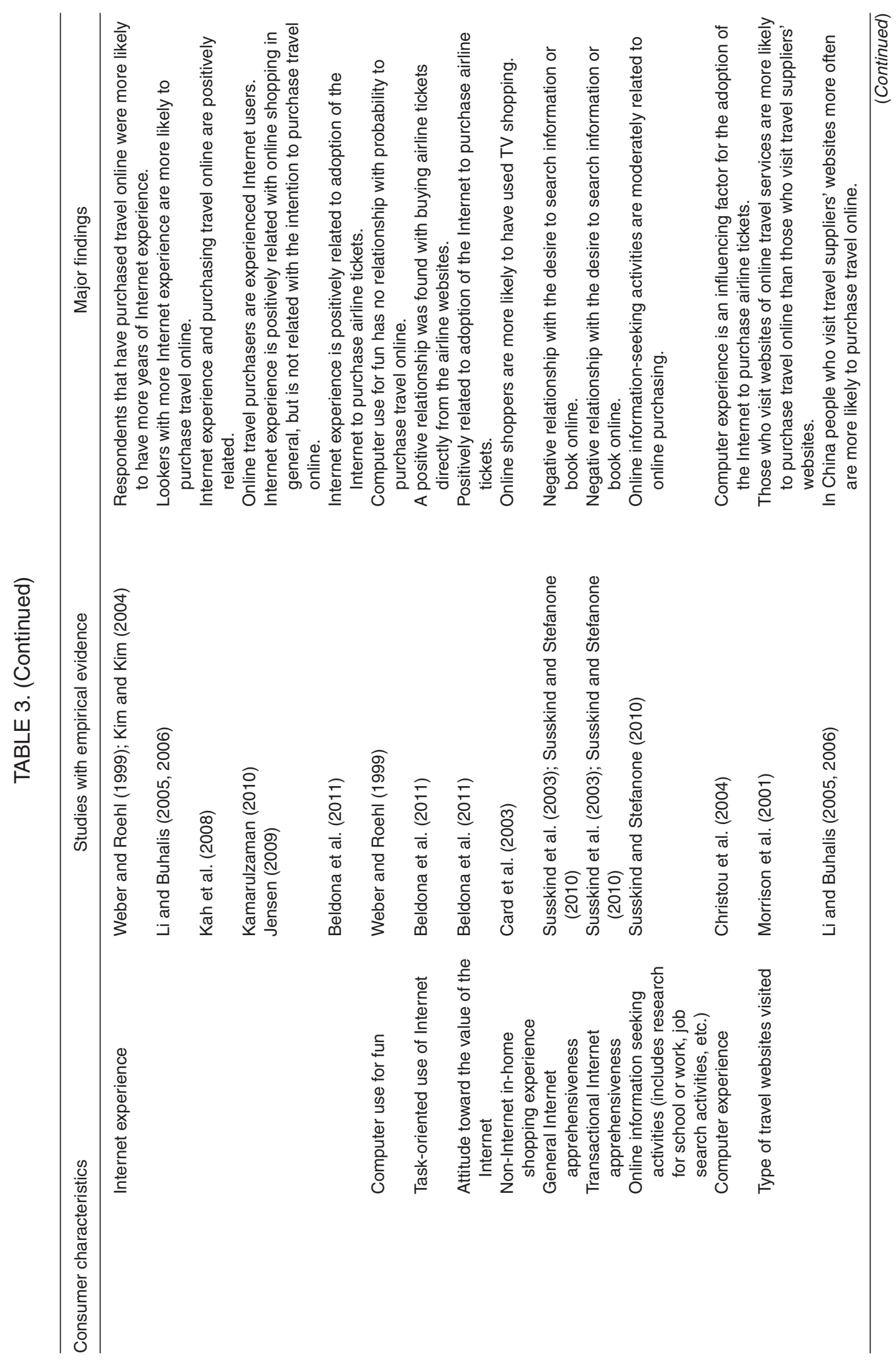




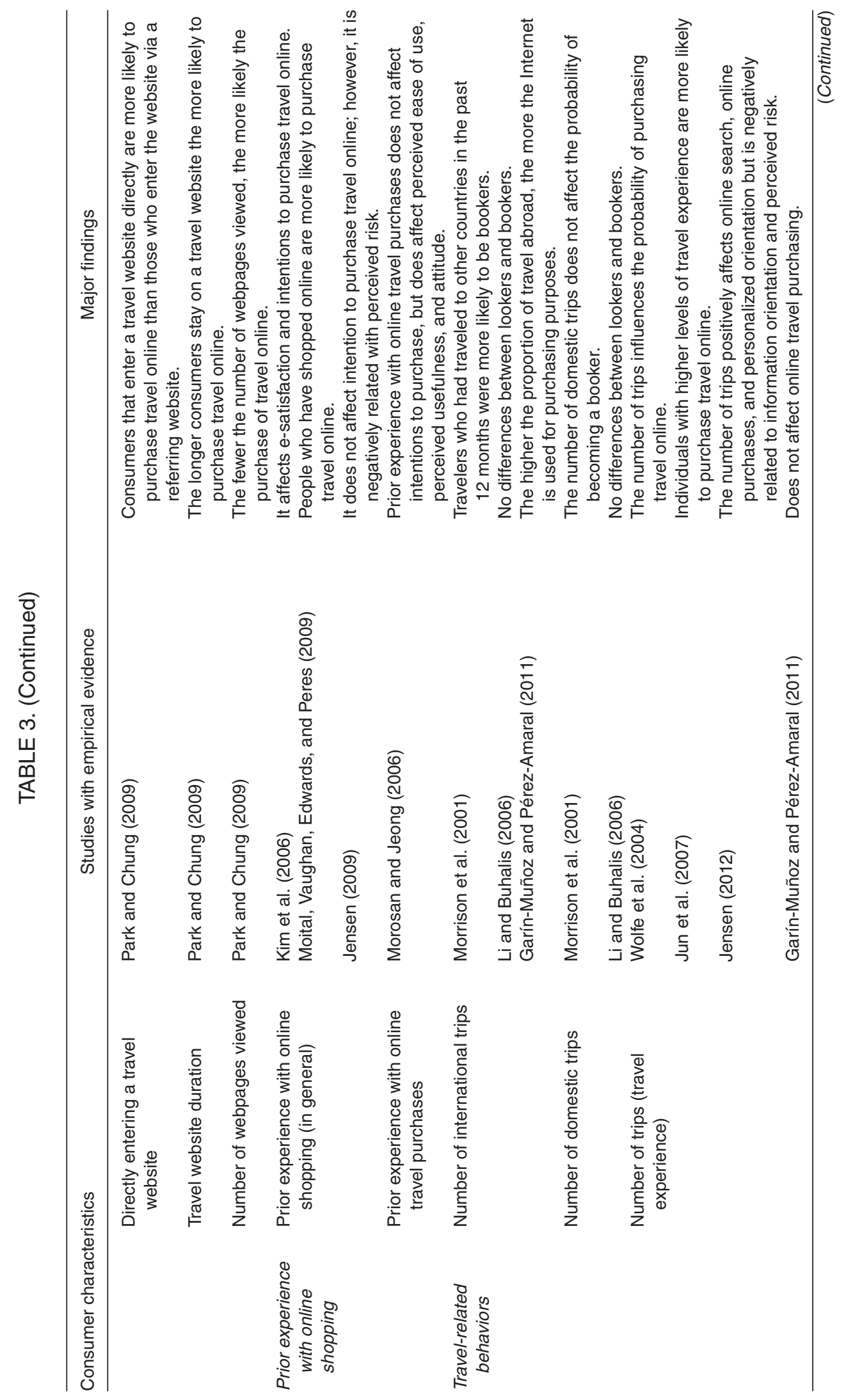




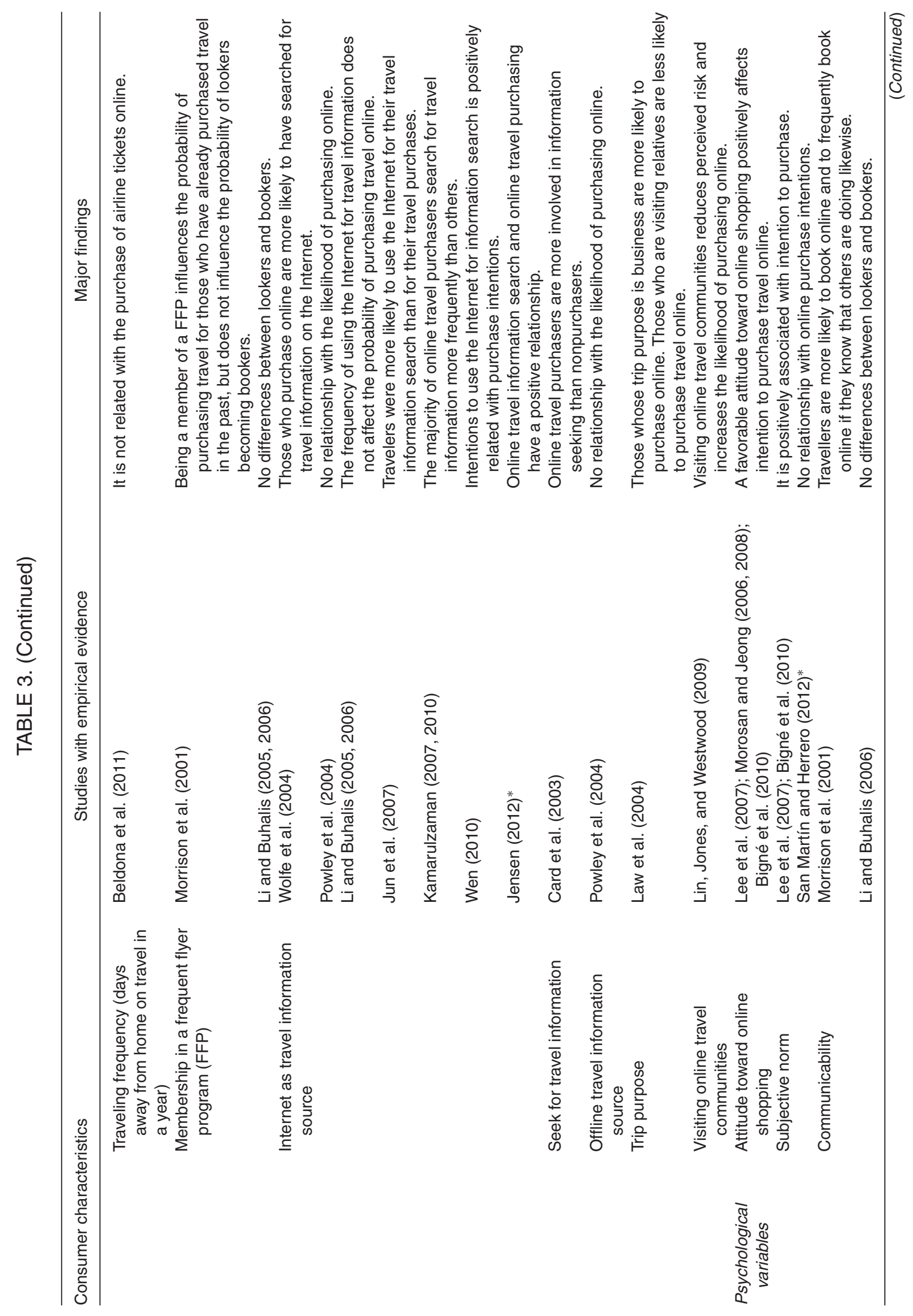




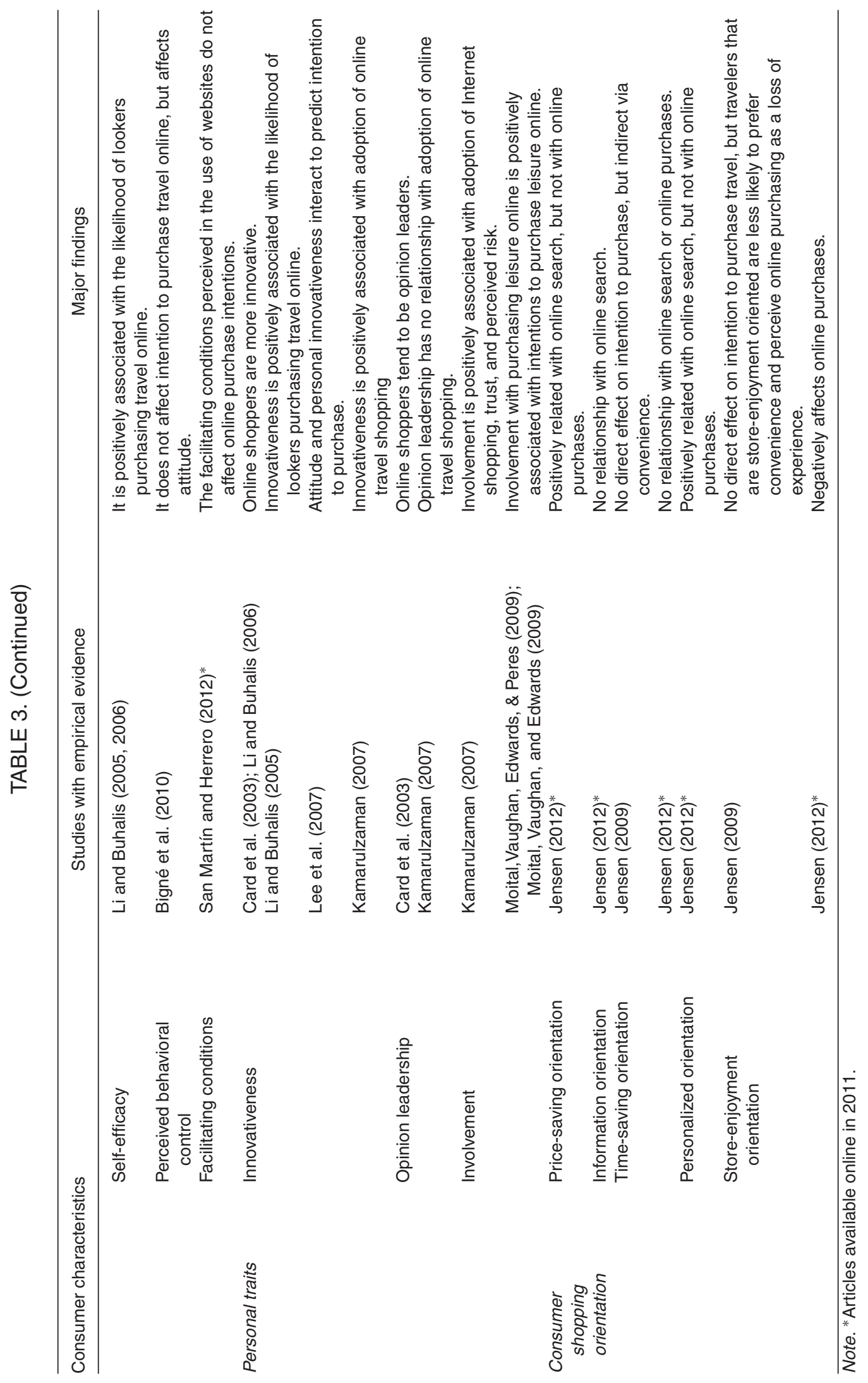




\section{Relative Advantages}

Grounded on Rogers' (1995) definition of relative advantages, the current study considers that relative advantages concern the degree to which online travel shopping provides benefits to consumers or is better than its alternatives.

Based on Chang et al.'s (2005) framework, two factors from Davis's (1989) technology acceptance model (TAM) - perceived usefulness and perceived ease of use-are categorized as relative advantages of online shopping. Applied to online shopping, perceived usefulness is "the extent to which a consumer believes that online shopping will provide access to useful information, facilitate comparison shopping, and enable quicker shopping"; while perceived ease of use is "the extent to which a consumer believes that on-line shopping is free of effort" (Vijayasarathy, 2004, p. 750). Cho and Agrusa (2006) found that perceived ease of use and usefulness affected consumer's attitude toward online travel agencies, which in turn affected consumers' satisfaction or intention to use.

Adding perceived playfulness to the original TAM, Morosan and Jeong $(2006,2008)$ examined the adoption of hotel reservation websites, and found that perceived usefulness, ease of use, and playfulness had an impact on attitudes toward using hotel reservation websites. Moreover, attitudes and perceived playfulness had an impact on users' intentions to use hotel reservation websites.

Kamarulzaman (2007) added perceived risk, trust, and e-consumers' personal characteristics to the original TAM to investigate which factors influenced UK consumers in the adoption of travel e-shopping. She found that perceived usefulness was positively correlated to the adoption of online travel shopping, but contrary to what was expected, perceived ease of use did not affect the adoption of online travel shopping directly. This suggests that user-friendly and easy to use websites are not decisive in the decision to purchase travel online. Nevertheless, researchers have found that perceived ease of use does have an indirect effect on the decision to purchase travel online, since it affects perceived usefulness, which in turn affects the adoption of online travel shopping (Bigné et al., 2010; Kamarulzaman, 2007).
More recently, San Martín and Herrero (2012) used the unified theory of acceptance and use of technology as a reference framework to explore variables influencing the intention to purchase rural tourism accommodation online. They found that performance expectancy and effort expectancy (concepts similar to perceived usefulness and perceived ease of use, respectively) have a positive influence on online purchase intention.

Convenience has been recognized as one of the main advantages of online travel shopping in numerous studies (e.g., Bai et al., 2004; Bogdanovych et al., 2006; Christou \& Kassianidis, 2003; Heung, 2003) and as a dimension affecting intention to book hotels online (Kim \& Kim, 2004; Kim et al., 2006) as well as intentions to purchase overall travel online (Jensen, 2009). Furthermore, convenience has been found to be strongly associated with e-satisfaction (Kim et al., 2006; Kolsaker et al., 2004), which in turn will affect the willingness to make future purchases (Kolsaker et al., 2004). Surprisingly, nonfinancial benefits such as convenience, ease of use, and selfsatisfaction with using the Internet for travel planning and booking were not found to be significant as advantages in Morrison et al.'s (2001) model to predict the probability of booking online.

Despite the importance of nonfinancial advantages, lower prices or further financial benefits are other advantages usually associated with online travel purchases (Morrison et al., 2001). Actually, a significant number of the articles reviewed provide evidence to support the importance of lower prices on consumers' decision to purchase travel online (e.g., Bai et al., 2004; Kim, Kim, \& Han, 2007; Kim et al., 2006; Li \& Buhalis, 2006; Wong \& Law, 2005). Notwithstanding several researchers' claims of the importance of price, $\mathrm{Ku}$ and Fan (2009) argue that consumers purchasing travel online consider privacy and safety more relevant than price.

\section{Relative Disadvantages}

In addition to risk, privacy, and trust issues, researchers have identified other factors that negatively affect the intention to purchase travel 
online and are, therefore, barriers to the adoption of online travel shopping. For instance, perceiving online travel shopping as a complex task has been pointed out in numerous studies as negatively affecting intentions to purchase travel online (Christou \& Kassianidis, 2003; Klein, Kohne, \& Oorni, 2004; Li \& Buhalis, 2005; Moital, Vaughan, \& Edwards, 2009; Morrison et al., 2001; Powley et al., 2004). Jensen (2009) argues that travelers who feel they have to give up hedonic aspects by not shopping at a travel agency, will be less likely to purchase online. Other reasons for not purchasing online are as follows: being uncomfortable with the Internet (Christou, Avdimiotis, Kassianidis, \& Sigala, 2004), the lack of experience (Wolfe et al., 2004), price discrepancies among travel websites (Klein et al., 2004), lack of personal service (Wolfe et al., 2004), and the preference for other alternatives (Heung, 2003; Kolsaker et al., 2004).

\section{Online Shopping Experience}

For many consumers, the online shopping experience refers to whether purchasing travel online is satisfying and entertaining. In the context of online travel shopping, researchers have approached online satisfaction differently. Several researchers consider that online travel satisfaction is related to previous satisfaction with online travel purchases. For instance, Kolsaker et al. (2004) examined customer satisfaction from their online experience with the purchase of airline tickets. The study found that online satisfaction with previous purchases lead to a higher intention to purchase airline tickets online. Kim et al.'s (2006) experimental findings also revealed that previous satisfaction with online shopping was the greatest determinant in explaining intention to book a hotel online.

Several researchers (Bai, Law, \& Wen, 2008; Law, Bai, \& Leung, 2008) have looked at online satisfaction from a different perspective, exploring satisfaction with the travel website, rather than with the overall shopping experience. These studies concluded that customer satisfaction with travel websites leads to a higher intention of purchasing online. In this context, customer satisfaction will be affected by website characteristics such as navigation functionality, perceived security, transaction cost, interactivity, customization, and website attractiveness (Bai et al., 2008; Khare \& Khare, 2010; Law \& Bai, 2008; Law et al., 2008).

Other factors identified as being associated with the online shopping experience affecting consumers' likelihood of purchasing travel online were: service performance and reputation (Kim et al., 2006), feeling confident with online shopping (Powley et al., 2004), perceiving it as enjoyable and entertaining (Morosan \& Jeong, 2006; Powley et al., 2004), and being compatible with consumers' lifestyle (Christou \& Kassianidis, 2003; Li \& Buhalis, 2006).

\section{Trust}

Surprisingly, only a few studies examined the effect of trust on online travel purchasing. Chen (2006) theorized that consumers' overall trust in online travel websites will influence their intention to purchase and McCole (2002) argued that trust has an important effect on the propensity to purchase online. More recently, Wen (2010) claimed that consumers' trust had a positive effect on intentions to purchase travel online.

Kamarulzaman (2007) did not find a direct effect of trust on the adoption of online travel shopping. Still, she did find that the more consumers trust online travel shopping, the lower their risk perception will be. Therefore, trust has an indirect effect on the adoption of online travel shopping since they will perceive a higher usefulness in online travel shopping and will be more likely to adopt it. Bigné et al. (2010) also found that trust had an indirect effect on intention to purchase airline tickets online as it had a significant influence on a favorable attitude toward the use of the Internet to purchase. Thus, regardless of being mediated by perceived risk or not, trust is vital to the success of online travel shopping.

The main findings of the effects of perceived channel characteristics on usage and intentions to purchase travel online are summarized in Table 4. 
TABLE 4. The Effects of Channel Characteristics on Intentions and Usage of Online Travel Purchasing

\begin{tabular}{|c|c|c|c|}
\hline \multicolumn{2}{|c|}{ Perceived channel characteristics } & \multirow{2}{*}{$\begin{array}{c}\text { Studies with } \\
\text { empirical evidence } \\
\text { Heung (2003); Wolfe } \\
\text { et al. (2004) }\end{array}$} & Major findings \\
\hline \multirow[t]{23}{*}{$\begin{array}{l}\text { Perceived } \\
\text { risk/security }\end{array}$} & $\begin{array}{l}\text { Concerns of } \\
\text { system security }\end{array}$ & & $\begin{array}{l}\text { Security issues were one of the most important } \\
\text { reasons why respondents had not purchased } \\
\text { travel online. }\end{array}$ \\
\hline & & Kim and Kim (2004) & Safety influences online reservation intention. \\
\hline & $\begin{array}{l}\text { Uncertainty of } \\
\text { reservation/cancel- } \\
\text { lation }\end{array}$ & Morrison et al. (2001) & $\begin{array}{l}\text { Consumers highly concerned with the uncertainty } \\
\text { of reservations are less likely to purchase online. }\end{array}$ \\
\hline & Credit card security & $\begin{array}{l}\text { Weber and Roehl } \\
\text { (1999) }\end{array}$ & Main reason for not purchasing travel online. \\
\hline & & Morrison et al. (2001) & $\begin{array}{l}\text { Consumers highly concerned with credit card fault } \\
\text { risk are less likely to purchase online. }\end{array}$ \\
\hline & $\begin{array}{l}\text { Unauthorized } \\
\text { secondary use of } \\
\text { data }\end{array}$ & $\begin{array}{l}\text { Brown et al. (2005, } \\
\text { 2007) }\end{array}$ & $\begin{array}{l}\text { Concerns with unauthorized secondary use of data } \\
\text { do not affect actual online travel purchases or } \\
\text { intention to purchase travel online. }\end{array}$ \\
\hline & Invasion of privacy & $\begin{array}{l}\text { Brown et al. (2005, } \\
\text { 2007) }\end{array}$ & $\begin{array}{l}\text { Concerns with invasion of privacy does not affect } \\
\text { actual online travel purchases or intention to } \\
\text { purchase travel online. }\end{array}$ \\
\hline & $\begin{array}{l}\text { Inaccuracy/manipu- } \\
\text { lation of personal } \\
\text { data }\end{array}$ & $\begin{array}{l}\text { Brown et al. (2005, } \\
\text { 2007) }\end{array}$ & $\begin{array}{l}\text { Concerns with manipulation of personal data do } \\
\text { not affect actual online travel purchases or } \\
\text { intention to purchase travel online. }\end{array}$ \\
\hline & $\begin{array}{l}\text { Concerns with } \\
\text { overall privacy }\end{array}$ & Ku and Fan (2009) & $\begin{array}{l}\text { Concerns with privacy were one of the main } \\
\text { factors considered by consumers purchasing } \\
\text { travel online. }\end{array}$ \\
\hline & $\begin{array}{l}\text { Overall perceived } \\
\text { risk }\end{array}$ & Kolsaker et al. (2004) & $\begin{array}{l}\text { Strong negative correlation with willingness to } \\
\text { purchase airline tickets online. }\end{array}$ \\
\hline & & $\begin{array}{l}\text { Kamarulzaman } \\
\quad(2007)\end{array}$ & $\begin{array}{l}\text { It is not associated with the adoption of online } \\
\text { travel shopping, but is negatively associated with } \\
\text { perceived usefulness. }\end{array}$ \\
\hline & & Ku and Fan (2009) & $\begin{array}{l}\text { One of the main factors considered by customers } \\
\text { purchasing travel online. }\end{array}$ \\
\hline & & Kim et al. (2009) & $\begin{array}{l}\text { Nonpurchasers perceive higher risks than online } \\
\text { purchasers when purchasing airline tickets } \\
\text { online. }\end{array}$ \\
\hline & & Bigné et al. (2010) & $\begin{array}{l}\text { It negatively affects trust and attitudes toward } \\
\text { online shopping. }\end{array}$ \\
\hline & & $\begin{array}{l}\text { Jensen }(2009 \text {, } \\
\text { 2012*) }\end{array}$ & $\begin{array}{l}\text { It negatively related with intention to purchase } \\
\text { travel online. }\end{array}$ \\
\hline & Financial risk & Kim et al. (2005) & $\begin{array}{l}\text { Financial risk is negatively associated with } \\
\text { intention to purchase online. }\end{array}$ \\
\hline & & Kim et al. (2009) & $\begin{array}{l}\text { Perceived much riskier by nonpurchasers than } \\
\text { online purchasers. }\end{array}$ \\
\hline & Performance risk & Kim et al. (2005) & $\begin{array}{l}\text { Performance risk is negatively associated with } \\
\text { intention to purchase travel online. }\end{array}$ \\
\hline & & Kim et al. (2009) & $\begin{array}{l}\text { The most influential risk in potential consumers } \\
\text { avoiding online purchases. }\end{array}$ \\
\hline & Psychological risk & Kim et al. (2005) & $\begin{array}{l}\text { Psychological risk is negatively associated with } \\
\text { intention to purchase travel online. }\end{array}$ \\
\hline & & Kim et al. (2009) & $\begin{array}{l}\text { It is perceived much riskier by nonpurchasers than } \\
\text { online purchasers. }\end{array}$ \\
\hline & Social risk & Kim et al. (2005) & $\begin{array}{l}\text { Social risk was negatively associated with intention } \\
\text { to purchase online. }\end{array}$ \\
\hline & & Kim et al. (2009) & $\begin{array}{l}\text { No differences of perceived social risk between } \\
\text { online purchasers and nonpurchasers. }\end{array}$ \\
\hline
\end{tabular}


TABLE 4. (Continued)

\begin{tabular}{|c|c|c|c|}
\hline \multicolumn{2}{|c|}{ Perceived channel characteristics } & \multirow{2}{*}{$\begin{array}{c}\begin{array}{c}\text { Studies with } \\
\text { empirical evidence }\end{array} \\
\text { Kim et al. (2005) }\end{array}$} & Major findings \\
\hline & Physical risk & & $\begin{array}{l}\text { Physical risk does not affect intention to purchase } \\
\text { travel online. }\end{array}$ \\
\hline & & Kim et al. (2009) & $\begin{array}{l}\text { No differences of perceived physical risk between } \\
\text { online purchasers and nonpurchasers. }\end{array}$ \\
\hline & Time risk & Kim et al. (2005) & $\begin{array}{l}\text { Time risk is negatively associated with intention to } \\
\text { purchase travel online. }\end{array}$ \\
\hline & & Kim et al. (2009) & $\begin{array}{l}\text { It is perceived much riskier by nonpurchasers than } \\
\text { online purchasers. }\end{array}$ \\
\hline & Security risk & Kim et al. (2005) & $\begin{array}{l}\text { It is negatively associated with intention to } \\
\text { purchase online. }\end{array}$ \\
\hline & & Kim et al. (2009) & $\begin{array}{l}\text { It is perceived much riskier by nonpurchasers than } \\
\text { online purchasers. }\end{array}$ \\
\hline \multirow[t]{20}{*}{$\begin{array}{l}\text { Relative } \\
\text { advantages }\end{array}$} & Convenience & Morrison et al. (2001) & $\begin{array}{l}\text { No relationship with the likelihood to purchase } \\
\text { travel online. }\end{array}$ \\
\hline & & Heung (2003) & One of the main reasons to purchase travel online. \\
\hline & & Kolsaker et al. (2004) & $\begin{array}{l}\text { Positive correlation with willingness to purchase } \\
\text { airline tickets online. }\end{array}$ \\
\hline & & Kim and Kim (2004) & It affects intention to purchase online. \\
\hline & & Bai et al. (2004) & $\begin{array}{l}\text { Main reason why college students purchase travel } \\
\text { online. }\end{array}$ \\
\hline & & Kim et al. (2006) & $\begin{array}{l}\text { It affects e-satisfaction and online purchase } \\
\text { intention. }\end{array}$ \\
\hline & & Ku and Fan (2009) & $\begin{array}{l}\text { Not a main factor attracting consumers to } \\
\text { purchase travel online. }\end{array}$ \\
\hline & & Mayr and Zins (2009) & Online shoppers value convenience. \\
\hline & & Jensen (2009) & $\begin{array}{l}\text { Consumers that value convenience are more likely } \\
\text { to purchase travel online. }\end{array}$ \\
\hline & Time saving & Morrison et al. (2001) & No relationship with online travel purchases. \\
\hline & & $\begin{array}{l}\text { Wong and Law } \\
\text { (2005) }\end{array}$ & Affects intention to purchase travel online. \\
\hline & & Heung (2003) & One of the main reasons to purchase travel online. \\
\hline & & $\begin{array}{l}\text { Christou \& } \\
\quad \text { Kassianidis (2003) }\end{array}$ & $\begin{array}{l}\text { The larger the perceived time pressure, the larger } \\
\text { the perceived relative advantage and perceived } \\
\text { compatibility of purchasing travel online. }\end{array}$ \\
\hline & Easy to order & Morrison et al. (2001) & $\begin{array}{l}\text { No relationship with intention to purchase travel } \\
\text { online. }\end{array}$ \\
\hline & Perceived ease & Morrison et al. (2001) & No relationship with the probability to book online. \\
\hline & $\begin{array}{l}\text { of use/effort } \\
\text { expectancy }\end{array}$ & $\begin{array}{l}\text { Morosan and Jeong } \\
\quad(2006,2008)\end{array}$ & $\begin{array}{l}\text { It has a positive impact on attitude toward hotel } \\
\text { reservation sites, on perceived playfulness, and } \\
\text { on perceived usefulness. }\end{array}$ \\
\hline & & $\begin{array}{l}\text { Cho and Agrusa } \\
\text { (2006) }\end{array}$ & $\begin{array}{l}\text { Affects consumer's attitude toward online travel } \\
\text { agencies, which in turn affects consumers' } \\
\text { satisfaction and intention to purchase travel } \\
\text { online. }\end{array}$ \\
\hline & & $\begin{array}{l}\text { Kamarulzaman } \\
\quad(2007)\end{array}$ & $\begin{array}{l}\text { It does not have a direct influence on the adoption } \\
\text { of online purchases, but has an impact on trust } \\
\text { and perceived usefulness. }\end{array}$ \\
\hline & & Bigné et al. (2010) & $\begin{array}{l}\text { Affects intentions to purchase airline tickets online } \\
\text { indirectly via perceived risk and trust. }\end{array}$ \\
\hline & & $\begin{array}{l}\text { San Martín and } \\
\quad \text { Herrero }(2012)^{*}\end{array}$ & It positively affects online purchase intention. \\
\hline
\end{tabular}


TABLE 4. (Continued)

\begin{tabular}{|c|c|c|c|}
\hline \multicolumn{2}{|c|}{ Perceived channel characteristics } & \multirow{2}{*}{$\begin{array}{c}\text { Studies with } \\
\text { empirical evidence } \\
\begin{array}{c}\text { Morosan and Jeong } \\
(2006,2008)\end{array}\end{array}$} & \multirow[t]{2}{*}{ Major findings } \\
\hline & $\begin{array}{l}\text { Perceived } \\
\text { usefulness/ } \\
\text { performance }\end{array}$ & & \\
\hline & expectancy & $\begin{array}{l}\text { Cho and Agrusa } \\
\qquad(2006)\end{array}$ & $\begin{array}{l}\text { Affects consumers' attitude toward online travel } \\
\text { agencies, which in turn affects consumers' } \\
\text { satisfaction and intentions to purchase travel } \\
\text { online. }\end{array}$ \\
\hline & & $\begin{array}{l}\text { Kamarulzaman } \\
\quad(2007)\end{array}$ & $\begin{array}{l}\text { It is positively associated with online travel } \\
\text { purchases. }\end{array}$ \\
\hline & & Bigné et al. (2010) & $\begin{array}{l}\text { Affects attitude toward the purchase of airline } \\
\text { tickets which in turn influences intentions to } \\
\text { purchase airline tickets online. }\end{array}$ \\
\hline & & $\begin{array}{l}\text { San Martín and } \\
\text { Herrero }(2012)^{*}\end{array}$ & It positively affects online purchase intentions. \\
\hline \multirow{6}{*}{\multicolumn{2}{|c|}{ Price }} & Morrison et al. (2001) & $\begin{array}{l}\text { Consumers tend to purchase online to get lower } \\
\text { prices. }\end{array}$ \\
\hline & & Kim and Kim (2004) & Price affects intention to purchase online. \\
\hline & & $\begin{array}{l}\text { Wong and Law } \\
(2005)\end{array}$ & $\begin{array}{l}\text { Price level was more important than web security } \\
\text { and web features. }\end{array}$ \\
\hline & & Beldona et al. (2005) & $\begin{array}{l}\text { Price motivates the purchase of less complex } \\
\text { travel online. }\end{array}$ \\
\hline & & Kim et al. (2006) & Price affects intentions to purchase travel online. \\
\hline & & Ku and Fan (2009) & $\begin{array}{l}\text { Price is not a main factor attracting consumers to } \\
\text { purchase travel online. Consumers consider } \\
\text { privacy, safety, and product quality more } \\
\text { important when purchasing travel online. }\end{array}$ \\
\hline & Finding low fares & Kim et al. (2007) & $\begin{array}{l}\text { Finding low fares was found to be the most critical } \\
\text { attribute for consumers to use online travel } \\
\text { agencies. }\end{array}$ \\
\hline & Special discounts & Morrison et al. (2001) & $\begin{array}{l}\text { Consumers looking for special discounts were } \\
\text { more likely to purchase online. }\end{array}$ \\
\hline & $\begin{array}{l}\text { Physical effort of } \\
\text { in-store travel } \\
\text { shopping }\end{array}$ & $\begin{array}{l}\text { Christou and } \\
\text { Kassianidis (2003) }\end{array}$ & $\begin{array}{l}\text { The larger the perceived physical effort of in-store } \\
\text { travel shopping, the larger the perceived relative } \\
\text { advantage of shopping for travel online. }\end{array}$ \\
\hline & $\begin{array}{l}\text { Overall relative } \\
\text { advantages }\end{array}$ & $\begin{array}{l}\text { Christou and } \\
\text { Kassianidis (2003); } \\
\text { Moital, Vaughan, } \\
\text { Edwards, and } \\
\text { Peres (2009) }\end{array}$ & $\begin{array}{l}\text { Higher levels of perceived relative advantages are } \\
\text { positively related to intentions to purchase travel } \\
\text { online. }\end{array}$ \\
\hline & Points/rewards & Beldona et al. (2005) & $\begin{array}{l}\text { Being offered points or rewards motivates the } \\
\text { purchase of less-complex travel online. }\end{array}$ \\
\hline & $\begin{array}{l}\text { Self-satisfaction of } \\
\text { planning travel by } \\
\text { own }\end{array}$ & Morrison et al. (2001) & It has no relationship with purchasing travel online. \\
\hline & $\begin{array}{l}\text { Overall financial } \\
\text { advantages }\end{array}$ & Li and Buhalis (2006) & $\begin{array}{l}\text { No significant differences between bookers and } \\
\text { lookers. }\end{array}$ \\
\hline & Product variety & Jensen (2009) & $\begin{array}{l}\text { A greater product variety influences consumers' } \\
\text { intention to purchase online. }\end{array}$ \\
\hline \multirow[t]{2}{*}{$\begin{array}{l}\text { Relative disad- } \\
\quad \text { vantages }\end{array}$} & Time consuming & Wolfe et al. (2005) & $\begin{array}{l}\text { Reported reason why people had not bought travel } \\
\text { online. }\end{array}$ \\
\hline & $\begin{array}{l}\text { Lack of personal } \\
\text { service }\end{array}$ & Wolfe et al. (2004) & $\begin{array}{l}\text { Lack of personal service was one of the reported } \\
\text { reasons why people had not bought travel } \\
\text { online. }\end{array}$ \\
\hline
\end{tabular}


TABLE 4. (Continued)

\begin{tabular}{|c|c|c|c|}
\hline \multicolumn{2}{|c|}{ Perceived channel characteristics } & \multirow{2}{*}{$\begin{array}{c}\text { Studies with } \\
\text { empirical evidence } \\
\text { Mayr and Zins (2009) }\end{array}$} & Major findings \\
\hline & & & $\begin{array}{l}\text { Nonshoppers value personal services of traditional } \\
\text { travel agencies. }\end{array}$ \\
\hline & $\begin{array}{l}\text { Loss of experience } \\
\text { with online }\end{array}$ & $\begin{array}{l}\text { Christou and } \\
\quad \text { Kassianidis (2003) }\end{array}$ & $\begin{array}{l}\text { No relationship with perceived relative advantage of } \\
\text { purchasing for travel online. }\end{array}$ \\
\hline & shopping & Jensen (2009) & $\begin{array}{l}\text { Negatively associated with intentions to purchase } \\
\text { travel online. }\end{array}$ \\
\hline & $\begin{array}{l}\text { Perceived } \\
\text { complexity }\end{array}$ & $\begin{array}{l}\text { Christou and } \\
\text { Kassianidis (2003); } \\
\text { Powley et al. } \\
\text { (2004); Li and } \\
\text { Buhalis (2005); } \\
\text { Klein et al. (2004); } \\
\text { Moital,Vaughan, } \\
\text { Edwards, and } \\
\text { Peres (2009) }\end{array}$ & $\begin{array}{l}\text { All studies found that perceived complexity is } \\
\text { negatively associated with intentions to purchase } \\
\text { travel online. }\end{array}$ \\
\hline \multirow[t]{10}{*}{$\begin{array}{l}\text { Online } \\
\text { satisfaction }\end{array}$} & $\begin{array}{l}\text { Customer } \\
\text { satisfaction }\end{array}$ & Kolsaker et al. (2004) & $\begin{array}{l}\text { Previous satisfaction with the purchase of airline } \\
\text { tickets online affects willingness to purchase airline } \\
\text { tickets online. }\end{array}$ \\
\hline & & $\begin{array}{l}\text { Law et al. (2008); } \\
\text { Law and Bai } \\
\text { (2008); Bai et al. } \\
\text { (2008) }\end{array}$ & $\begin{array}{l}\text { Customer satisfaction with travel websites affects } \\
\text { intentions to purchase travel online. }\end{array}$ \\
\hline & & Kim et al. (2006) & $\begin{array}{l}\text { Previous satisfaction with online travel shopping was } \\
\text { the greatest determinant in explaining intention to } \\
\text { book a hotel online. }\end{array}$ \\
\hline & $\begin{array}{l}\text { Perceived } \\
\text { compatibility }\end{array}$ & $\begin{array}{l}\text { Christou and } \\
\text { Kassianidis (2003); } \\
\text { Li and Buhalis } \\
\text { (2006) }\end{array}$ & $\begin{array}{l}\text { Both studies found that perceived compatibility is } \\
\text { positively associated with intention to purchase } \\
\text { travel online. }\end{array}$ \\
\hline & Enjoyable & Powley et al. (2004) & $\begin{array}{l}\text { Positive relationship with likelihood of purchasing } \\
\text { travel online. }\end{array}$ \\
\hline & Confident & Powley et al. (2004) & $\begin{array}{l}\text { Positive relationship with likelihood of purchasing } \\
\text { travel online. }\end{array}$ \\
\hline & & Li and Buhalis (2006) & $\begin{array}{l}\text { Lookers and bookers showed the same degree of } \\
\text { confidence in using the Internet to purchase travel. }\end{array}$ \\
\hline & Entertaining & $\begin{array}{l}\text { Cho and Agrusa } \\
\text { (2006) }\end{array}$ & $\begin{array}{l}\text { Entertainment affects perceived ease of use and } \\
\text { perceived usefulness, which in turn affects } \\
\text { intentions to purchase travel online. }\end{array}$ \\
\hline & $\begin{array}{l}\text { Perceived } \\
\text { playfulness }\end{array}$ & $\begin{array}{l}\text { Morosan and Jeong } \\
(2006,2008)\end{array}$ & $\begin{array}{l}\text { Perceived playfulness affects attitudes toward using } \\
\text { hotel reservation sites and intentions to use hotel } \\
\text { websites for purchasing. }\end{array}$ \\
\hline & $\begin{array}{l}\text { Service } \\
\text { performance and } \\
\text { reputation }\end{array}$ & Kim et al. (2006) & $\begin{array}{l}\text { Service performance and reputation does not affect } \\
\text { e-satisfaction, but affects online purchase intention. }\end{array}$ \\
\hline \multirow[t]{5}{*}{ Trust } & Overall trust & McCole (2002) & $\begin{array}{l}\text { Trust is important to consumers who purchase travel } \\
\text { online. }\end{array}$ \\
\hline & & Chen (2006) & $\begin{array}{l}\text { Theorizes that overall trust influences consumer } \\
\text { intention and adoption of purchasing travel online. }\end{array}$ \\
\hline & & $\begin{array}{l}\text { Kamarulzaman } \\
\quad(2007)\end{array}$ & $\begin{array}{l}\text { Trust has a positive impact on perceived risk, but does } \\
\text { not have a direct impact on online travel shopping. }\end{array}$ \\
\hline & & Bigné et al. (2010) & $\begin{array}{l}\text { Trust positively affects attitude towards purchasing } \\
\text { airline tickets online which in turn influences } \\
\text { intentions to purchase airline tickets online. }\end{array}$ \\
\hline & & Wen (2010) & $\begin{array}{l}\text { Trust has a positive impact on online purchase } \\
\text { intentions. }\end{array}$ \\
\hline
\end{tabular}




\section{Website and Product Characteristics}

\section{Website Features}

Despite the growing body of literature about website quality assessment in the tourism and hospitality fields (see Ip et al., 2011; Law, Qi, \& Buhalis 2010), there is still a lack of research regarding the relationship between website quality and online consumers' behavior (Bai et al., 2008). Indeed, few studies establish a relationship between website characteristics and intentions to purchase travel online or actual usage. The few existent studies suggest that a good website design has a significant effect on consumers' online purchase intentions (Wen, 2010) and on consumers' trust (Chen, 2006). Consumers that had enjoyable experiences on the website are more willing to purchase travel online (Powley et al., 2004). Bai et al. (2008) and Law et al. (2008) suggested that website quality, measured by usability and functionality dimensions, had an indirect influence on purchase intentions through customer satisfaction. Lin, Jones, and Westwood (2009) noted that the use of pictures and the presence of contact information on travel websites reduced the perceived risk of online travel purchase by Taiwanese consumers. Regardless of the importance of website design on consumers online behavior, Wong and Law (2005) found that price was more important than web features when booking hotel rooms online.

\section{Product Characteristics}

Travel products can be classified based on their complexity (Beldona, Morrison, \& O'Leary, 2005). Beldona et al. (2005) classify products such as flights, accommodation, and car rentals as low-complexity travel products; while land-based holidays, cruises, and tours are considered high complexity (Beldona et al., 2005). Another distinction comes from Anckar and Walden (2001), who classify domestic travel and single-leg flights as lowcomplexity travel arrangements, whereas international travel with multi-legged flights are considered high-complexity travel arrangements. Bogdanovych et al. (2006) found that the majority of the respondents of their study, which were heavy computer users, prefer booking their international trips from a travel agent, while domestic trips are usually booked online. Law et al. (2004) also observed that short-haul travelers' perception of the online channel was much more positive than long-haul travelers.

This distinction between high- and lowcomplex travel is important since travelers' motivations to purchase online vary across low- and high-complex travel products (Beldona et al., 2005). However, very few studies have related travel complexity to online travel purchasing usage or intentions.

The main findings of the effects of website and product characteristics on intentions to purchase travel online and actual usage are summarized in Table 5.

\section{DISCUSSION AND FUTURE RESEARCH DIRECTIONS}

As the literature review has shown, prior work on online travel shopping has focused on several antecedents of online travel shopping and has included theories that were originally from other fields (e.g., TAM, TRA, and TPB). Nevertheless, understanding travelers' purchase behavior online is still a challenging issue and there are several research gaps that can be explored.

Consumer characteristics and the perceived channel characteristics have been the most researched variables. Even so, the findings in these categories present contradictory results. For example, the relationship between online travel search and online travel purchases is not clear. Another example is opinion leadership; Kamarulzaman (2007) found that it did not have an effect on the adoption of online travel, while Card et al. (2003) claimed that online travel purchasers tended to be opinion leaders. Future research should be undertaken in order to clear contradictory results or investigate findings that have not been fully explored.

Website and product characteristics is clearly the category with the least amount of studies. Most studies concerning website evaluation in Tourism research usually generate performance indices or scores to capture the 
TABLE 5. The Effects of Website and Product Characteristics on Intentions and Usage of Online Travel Purchasing

\begin{tabular}{|c|c|c|c|}
\hline \multicolumn{2}{|c|}{ Website and product characteristics } & \multirow{2}{*}{$\begin{array}{l}\text { Studies with empirical evidence } \\
\text { Law and Bai (2008); Bai et al. } \\
\text { (2008); Law, et al. (2008) }\end{array}$} & \multirow{2}{*}{$\begin{array}{l}\text { Major findings } \\
\text { Functionality is positively associated } \\
\text { with customer satisfaction and } \\
\text { online purchase intentions. }\end{array}$} \\
\hline Website features & Functionality & & \\
\hline & Usability & $\begin{array}{l}\text { Law and Bai (2008); Law et al. } \\
\text { (2008); Bai et al. (2008) }\end{array}$ & $\begin{array}{l}\text { Usability is positively associated with } \\
\text { customer satisfaction and online } \\
\text { purchase intention. }\end{array}$ \\
\hline & Information quality & Wong and Law (2005) & $\begin{array}{l}\text { It is positively associated with } \\
\text { intentions to purchase travel } \\
\text { online. }\end{array}$ \\
\hline & & Beldona et al. (2005) & $\begin{array}{l}\text { Information quality motivates the } \\
\text { purchase of more complex travel } \\
\text { online. }\end{array}$ \\
\hline & & Kim et al. (2006) & $\begin{array}{l}\text { Affects e-satisfaction, but not } \\
\text { purchase intention. }\end{array}$ \\
\hline & $\begin{array}{l}\text { Overall website } \\
\text { quality }\end{array}$ & Powley et al. (2004) & $\begin{array}{l}\text { No association with the likelihood of } \\
\text { purchasing travel online. }\end{array}$ \\
\hline & & Wen (2010) & $\begin{array}{l}\text { It positively affects consumer trust, } \\
\text { search intentions, and online } \\
\text { purchase intentions. }\end{array}$ \\
\hline & Risk relievers & Lin et al. (2009) & $\begin{array}{l}\text { Risk relievers (e.g., security label } \\
\text { and privacy policy) have a positive } \\
\text { impact on consumers' decision to } \\
\text { purchase travel online. }\end{array}$ \\
\hline \multirow[t]{2}{*}{$\begin{array}{l}\text { Product } \\
\quad \text { characteristics }\end{array}$} & $\begin{array}{l}\text { Short haul, long } \\
\text { haul }\end{array}$ & Law et al. (2004) & $\begin{array}{l}\text { Short-haul travelers have a more } \\
\text { positive perception of the online } \\
\text { channel than long-haul travelers. } \\
\text { However, they were less willing to } \\
\text { purchase online than long-haul } \\
\text { travelers. }\end{array}$ \\
\hline & $\begin{array}{l}\text { Domestic flights, } \\
\text { international } \\
\text { flights }\end{array}$ & Bogdanovych et al. (2006) & $\begin{array}{l}\text { Travelers prefer booking their } \\
\text { international trips from a travel } \\
\text { agent, while domestic trips are } \\
\text { usually booked online. }\end{array}$ \\
\hline
\end{tabular}

overall quality of a website (Law et al., 2010) and do not relate the website evaluation with the purchase of travel online. Thus, research regarding website quality should go beyond simply ascertaining whether certain website dimensions/attributes are present to considering which dimensions/attributes have the greatest impact and consumer intentions to purchase (Ip et al., 2011).

The majority of the studies focus on travel products without distinguishing specific product categories. However, as previously noted, some travel-related services such as flights, accommodation, and car rentals are categorized as lowcomplexity travel products; while land-based holidays, cruises, and tours are considered high complexity. This distinction is acknowledged in a few studies that have shown that online shopping motivations differed for the two categories. Although several studies focused specifically on low-complexity travel services, such as accommodation (e.g., Kim \& Kim, 2004) or airline tickets (e.g., Kim et al., 2009), no research study focuses exclusively on high-complexity products. Thus, further studies should study online purchasing motivations considering distinct travel product categories rather than considering travel as one category. Moreover, further studies should be conducted specifically to compare high- and low-complexity products.

Research on online travel purchasing behavior has been majorly conducted with travelers 
TABLE 6. Article Distribution by Travel Products and Services and by Region

\begin{tabular}{|c|c|c|c|c|c|c|c|c|c|c|c|c|c|c|}
\hline $\begin{array}{l}\text { Travel products and } \\
\text { services }\end{array}$ & 1999 & 2000 & 2001 & 2002 & 2003 & 2004 & 2005 & 2006 & 2007 & 2008 & 2009 & 2010 & 2011 & Total \\
\hline Airline tickets & - & - & - & - & - & 2 & 2 & - & - & - & 1 & 1 & 1 & 7 \\
\hline Accomodation & - & - & - & - & - & 1 & 1 & 2 & - & 1 & - & - & 1 & 6 \\
\hline $\begin{array}{l}\text { Travel in general } \\
\text { Region }\end{array}$ & 1 & - & 1 & 1 & 4 & 2 & 4 & 4 & 5 & 5 & 7 & 4 & 3 & 41 \\
\hline Asia & - & - & - & - & - & 2 & 1 & 2 & 2 & 1 & 2 & - & 2 & 11 \\
\hline China & - & - & - & - & - & 1 & 1 & 2 & & 1 & 2 & - & - & 7 \\
\hline Korea & - & - & - & - & - & 1 & - & - & 1 & - & - & - & - & 2 \\
\hline India & - & - & - & - & - & - & - & - & - & - & - & - & 2 & 2 \\
\hline America & 1 & - & 1 & - & 2 & 2 & 3 & 3 & 1 & 2 & 2 & 2 & - & 19 \\
\hline USA + Canada & - & - & - & - & - & 1 & 1 & - & - & - & - & - & - & 2 \\
\hline Canada & - & - & - & - & - & - & - & - & - & 1 & - & - & - & 1 \\
\hline USA & 1 & - & 1 & - & 2 & 1 & 2 & 3 & 2 & 1 & 2 & 2 & - & 17 \\
\hline Europe & - & - & - & - & - & - & - & - & - & - & - & - & - & 14 \\
\hline Austria & - & - & - & - & - & - & - & - & - & - & 1 & - & - & 1 \\
\hline Denmark & - & - & - & - & - & - & - & - & - & - & - & 1 & 1 & 2 \\
\hline Finland & - & - & 1 & - & - & - & - & - & - & - & - & - & - & 1 \\
\hline $\begin{array}{l}\text { Finland and } \\
\text { Germany }\end{array}$ & - & - & - & - & - & - & 1 & - & - & - & - & - & - & 1 \\
\hline Greece & - & - & - & - & 1 & 1 & & - & - & - & - & - & - & 2 \\
\hline Portugal & - & - & - & - & - & - & - & - & - & - & 2 & - & - & 2 \\
\hline Spain & - & - & - & - & - & - & - & - & - & - & - & 1 & 1 & 2 \\
\hline UK & - & - & - & 1 & - & - & - & - & 1 & - & - & 1 & - & 3 \\
\hline Oceania & - & - & - & - & - & - & 1 & 1 & 1 & - & - & - & - & 3 \\
\hline Worldwide & - & - & - & - & - & - & - & - & - & - & - & - & - & 6 \\
\hline $\begin{array}{l}\text { China, Taiwan, } \\
\text { Singapore, } \\
\text { Malaysia, USA, } \\
\text { Australia and } \\
\text { Western Europe }\end{array}$ & - & - & - & - & - & 1 & 1 & - & - & 1 & - & - & - & 3 \\
\hline $\begin{array}{l}\text { China, Canada, } \\
\text { Taiwan, } \\
\text { Singapore, USA, } \\
\text { Australia, } \\
\text { Malaysia }\end{array}$ & - & - & - & - & 1 & - & - & - & - & - & - & - & - & 1 \\
\hline $\begin{array}{c}\text { Australia, UK and } \\
\text { North America }\end{array}$ & - & - & - & - & - & - & - & - & - & 1 & - & - & - & 1 \\
\hline China and USA & - & - & - & - & - & - & - & - & - & 1 & - & - & - & 1 \\
\hline
\end{tabular}

from the United States and China (see Table 6). Studies should be conducted in other countries in order to confirm and generalize results. On the other hand, although six studies used travelers from different countries, only one (Law et al., 2008) conducted a cross-cultural comparison. Consumers in different countries have different shopping preferences due to cultural differences (Kim \& Lee, 2006) and this should be further researched. Law et al. (2008) consider that the influence of culture on Internet usage is still a relatively unexplored field and that more work should be performed to further examine this issue.
Another relatively unexplored field is the effect of the purpose of travel on online travel purchasing behavior. For example, Law et al. (2004) found that international travelers visiting relatives purchased less online than those who traveled for leisure, business, or to visit friends. No other studies addressed this issue, but numerous studies have tried to provide useful profiles of travelers that purchase online, mainly by using demographic variables. Surprisingly, only one study (Moital, Vaughan, \& Edwards, 2009) conducted a cluster analysis to identify market segments with similar views toward online travel purchasing. It would be useful to 
carry out other segmentation studies using different measures such as shopping motivations, personality, or attitudes. Furthermore, it would be interesting to identify which variables most influence online travel shopping behavior for each segment in order to develop online marketing strategies that meet the needs of each segment.

Social media are a very interesting topic to explore. The evolution of the social Internet is changing how people search, shop for, and purchase travel (PhoCusWright, 2011). Online social networking applications have become highly popular throughout the hospitality industry (Kasavana, Nusair, \& Teodosic, 2010). Not only do they offer the opportunity for businesses to interact with their customers, but customers are able to interact with other customers. It is believed that online social networking will play a crucial role in online transactions (Kasavana et al., 2010). Several studies have confirmed the importance of social media in searching for travel information and the important role they have in the trip planning and purchase decision-making process (Gretzel \& Yoo, 2008; Gretzel, Yoo, \& Purifoy, 2007; O'Connor, 2008; Xiang \& Gretzel, 2010). Therefore, future research needs to address the relationship between social media use and online travel purchasing behavior. For example, a traveler's use of user-generated content or being a member of a travel community, such as Tripadvisor, could predict online travel shopping behavior.

In Law et al.'s (2004) study, respondents felt that travel agencies were better than travel websites in terms of human touch and personal services. However, as Hassanein and Head (2007) have reported, it is possible to integrate human warmth and sociability through the web interface to positively impact consumer attitudes toward online shopping. Their study, in the particular context of clothing, revealed that the perception of social presence on a commercial website had a positive impact on perceived usefulness, trust, and enjoyment, which in turn positively affect attitudes toward online shopping. Future investigations could examine the potential impact of social presence on online purchase intentions and actual purchases along with how social presence may help to build trust and reduce consumers' perceived risk, particularly in the travel and tourism industry.

Another interesting finding to explore is travelers' prior experience with online shopping of other products and services since it appears to have had no direct effect on their intentions to purchase travel online (Jensen, 2009). Future investigations could examine if there are any particular reasons for online shoppers of other products and services not to buy travel online and if there are any perceived differences.

Few studies have focused on personality traits of those who purchase travel online. It is known that online travel purchasers tend to be innovative, more high-tech prone and have higher degrees of involvement. Yet, further investigations should address the role of personality on online travel purchasing behavior. It would be valuable to incorporate theories and models from other academic disciplines such as psychology and sociology.

Many studies have focused on intentional behavior rather than the actual behavior. Although past studies have proven that intention leads to actual behavior, this is questionable with online travel shopping. For instance, Shao and Gretzel (2010) found that a high percentage of travelers abandon travel websites after searching for a hotel room and before submitting the final confirmation. Future research should assert this relationship between intention and actual behavior, in the specific context of online travel shopping.

\section{FINAL REMARKS, IMPLICATIONS, AND LIMITATIONS}

Online travel shopping has attracted researchers due to its significant growth and there is a growing body of literature in this field. This study reviewed 54 articles published between 1999 and 2011 in leading tourism journals, highlighting the main contributions of these studies to the tourism field. Moreover, a clear and comprehensive review of factors that affect online travel shopping was provided by categorizing all of the variables identified into three main groups: consumer characteristics, 
perceived channel characteristics, and website and product characteristics. Such a thorough review enabled the identification of several gaps and suggestions of research directions.

Indeed, further research should be conducted for several reasons. First, as aforementioned, several determinants of online travel shopping have been clearly overlooked. For instance, the relationship between social media with the purchase of travel online has never been carried out. Second, research should also be undertaken to clarify contradictory results. In some cases, the contradictory findings may be the result of researchers' different approaches to the same construct (e.g., online shopping experience). However, in several studies it is not clear how researchers conceptualize certain constructs. Thus, to facilitate comparisons with other studies, this study recommends researchers to provide a clear definition of the constructs included in their studies and how they were operationalized. Finally, research on online travel shopping has typically been fragmented. The literature review has revealed that there is a lack of studies that integrate several constructs to better understand online travel shopping and determine which factors are indeed more important to consumers.

A major limitation of this study is that the literature review is predominantly based on articles from tourism and travel journals. The review could be enriched with articles from other academic journals that address online travel shopping. On the other hand, although a structured methodology was conducted to search for suitable articles, it is possible that some relevant articles could be missing. In fact, articles may occasionally address online travel purchase, but they may not be explicit through the title or keywords, making it difficult to spot these articles.

In spite of these limitations, academic researchers, tourism practitioners, and marketers can take advantage of this study to better understand the work that has been carried out in the area of online travel shopping. Practitioners and marketers can identify variables that influence the purchase of travel online and consequently improve online travel distribution strategies. Understanding online traveler's buying behavior is important to implement successful online marketing strategies (Lee et al., 2007). In the academic field, it is expected that this research will make an important contribution to the current body of literature by extending the knowledge on the purchase of travel online. Furthermore, the research gaps identified also provide researchers with challenging directions for future research.

\section{NOTE}

1. Online travel purchase intentions are derived from Fishbein and Ajzen's (1975) theory of reasoned action that posits that behavioral intentions are the main predictors of actual behavior. Behavioral intentions have been well established as a strong predictor of online shopping (e.g., Ajzen, 2011; Chen, Gillenson, \& Sherrell, 2002; Limayem, Khalifa, \& Frini, 2000; Lin, 2007; Pavlou \& Fygenson, 2006).

\section{REFERENCES}

Ajzen, I. (1991). The theory of planned behavior. Organizational Behavior and Human Decision Processes, 50(2), 179-211.

Ajzen, I. (2002). Perceived behavioral control, selfefficacy, locus of control, and the theory of planned behavior. Journal of Applied Social Psychology, 32(4), $665-683$

Ajzen, I. (2011). Behavioral interventions: Design and evaluation guided by the theory of planned behavior. In M. M. Mark, S. I. Donaldson, \& B. C. Campbell (Eds.), Social psychology for program and policy evaluation (pp. 74-100). New York, NY: Guilford.

Anckar, B., \& Walden, P. (2001). Self-booking of high- and low-complexity travel products: Exploratory findings. Information Technology \& Tourism, 4(3-4), 151-165.

Arendt, S. W., Ravichandran, S., \& Brown, E. (2007). Hospitality and tourism journal matrix. Journal of Hospitality \& Tourism Education, 19(2), 44-50.

Bai, B., Hu, C., Elsworth, J., \& Countryman, C. (2004). Online travel planning and college students. Journal of Travel \& Tourism Marketing, 17(2-3), 79-91.

Bai, B., Law, R., \& Wen, I. (2008). The impact of website quality on customer satisfaction and purchase intentions: Evidence from Chinese online visitors. International Journal of Hospitality Management, 27(3), 391-402.

Beldona, S., Morrison, A., \& O’Leary, J. (2005). Online shopping motivations and pleasure travel products: A correspondence analysis. Tourism Management, 26(4), 561-570. 
Beldona, S., Nusair, K., \& Demicco, F. (2009). Online travel purchase behavior of generational cohorts: A longitudinal study. Journal of Hospitality Marketing \& Management, 18(4), 406-420.

Beldona, S., Racherla, P., \& Mundhra, G. D. (2011). To buy or not to buy: Indian consumers' choice of online versus offline channels for air travel purchase. Journal of Hospitality Marketing \& Management, 20(8), 831-854.

Bigné, E., Sanz, S., Ruiz, C., \& Aldás, J. (2010). Why some Internet users don't buy air tickets online. In U. Gretzel, R. Law, \& M. Fuchs (Eds.), Information and communication technologies in tourism 2010 (pp. 209-221). Vienna, Austria: Springer.

Bogdanovych, A., Berger, H., Simoff, S., \& Sierra, C. (2006). Travel agents vs. online booking: Tackling the shortcomings of nowadays online tourism portals. In M. Hitz, M. Sigala, \& J. Murphy (Eds.), Information and communication technologies in tourism 2006 (pp. 418-428). Vienna, Austria: Springer.

Brown, M. R., Muchira, R., \& Gottlieb, U. (2005). Privacy concerns and purchase of travel product online. In A. J. Frew (Ed.), Information and communication technologies in tourism 2005 (pp. 285-295). Vienna, Austria: Springer.

Brown, M. R., Muchira, R., \& Gottlieb, U. (2007). Privacy concerns and the purchasing of travel services online. Information Technology \& Tourism, 9(1), 15-25.

Buhalis, D. (1998). Strategic use of information technologies in the tourism industry. Tourism Management, 19(5), 409-421.

Buhalis, D., \& Law, R. (2008). Progress in information technology and tourism management: 20 years on and 10 years after the Internet-The state of eTourism research. Tourism Management, 29(4), 609-623.

Card, J. A., Chen, C.-Y., \& Cole, S. T. (2003). Online travel products shopping: Differences between shoppers and nonshoppers. Journal of Travel Research, 42(2), 133-139.

Chang, M. K., Cheung, W., \& Lai, V. S. (2005). Literature derived reference models for the adoption of online shopping. Information \& Management, 42(4), 543-559.

Chen, C. (2006). Identifying significant factors influencing consumer trust in an online travel site. Information Technology \& Tourism, 8(3-4), 197-214.

Chen, L., Gillenson, M. L., \& Sherrell, D. L. (2002). Enticing online consumers: An extended technology acceptance perspective. Information \& Management, 39(8), 705-719.

Cho, Y. C., \& Agrusa, J. (2006). Assessing use acceptance and satisfaction toward online travel agencies. Information Technology \& Tourism, 8(3), 179-195.

Christou, E., Avdimiotis, S., Kassianidis, P., \& Sigala, M. (2004). Examining the factors influencing the adoption of web-based ticketing: Etix and its adopters. In A. J. Frew (Ed.), Information and communication technologies in tourism 2004 (pp. 129-138). Vienna, Austria: Springer
Christou, E., \& Kassianidis, P. (2003). Consumer's perceptions and adoption of online buying for travel products. Journal of Travel \& Tourism Marketing, 12(4), 93-107.

Davis, F. D. (1989). Perceived usefulness, perceived ease of use, and user acceptance of information technology. MIS Quarterly, 13(3), 319-340.

Fishbein, M., \& Ajzen, I. (1975). Belief, attitude, intention and behaviour: An introduction to theory and research. Reading, MA: Addison-Wesley.

Garín-Muñoz, T., \& Pérez-Amaral, T. (2011). Internet usage for travel and tourism: The case of Spain. Tourism Economics, 17(5), 1071-1085.

Gehrt, K. C., \& Carter, K. (1992). An exploratory assessment of catalog shopping orientations: The existence of convenience and recreational segments. Journal of Direct Marketing, 6(1), 29-39.

George, J. F. (2004). The theory of planned behavior and Internet purchasing. Internet Research, 14(3), 198-212.

Gretzel, U., \& Yoo, K. H. (2008). Use and impact of online travel reviews. In P. O'Connor, W. Hopken, \& U. Gretzel (Eds.), Information and communication technologies in tourism 2008 (pp. 35-46). Vienna, Austria: Springer.

Gretzel, U., Yoo, K. H., \& Purifoy, M. (2007). Online travel review study: Role \& impact of online travel reviews. College Station, TX: Texas A\&M University, Laboratory for Intelligent Systems in Tourism.

Hassanein, K., \& Head, M. (2007). Manipulating perceived social presence through the web interface and its impact on attitude towards online shopping. International Journal of Human-Computer Studies, 65(8), 689-708.

Heung, V. C. S. (2003). Internet usage by international travellers: Reasons and barriers. International Journal of Contemporary Hospitality Management, 15(7), 370-378.

Hung, Y.-C., Yang, Y.-L., Yang, H.-E., \& Chuang, Y.-H. (2011). Factors affecting the adoption of e-commerce for the tourism industry in Taiwan. Asia Pacific Journal of Tourism Research, 16(1), 105-119.

Ip, C., Law, R., \& Lee, H. A. (2011). A review of website evaluation studies in the tourism and hospitality fields from 1996 to 2009. International Journal of Tourism Research, 13(3), 234-265.

ISI Web of Science. (2010). Journal citation reports. Retrieved from http://admin-apps.webofknowledge. com/JCR/JCR

Jamal, T., Smith, B., \& Watson, E. (2008). Ranking, rating and scoring of tourism journals: Interdisciplinary challenges and innovations. Tourism Management, 29(1), 66-78.

Jensen, J. M. (2009). Travellers' intentions to purchase travel products online: The role of shopping orientation. In A. Matias, P. Nijkamp, \& M. Sarmento (Eds.), Advances in tourism economics: New developments (pp. 203-215). Heidelberg, Germany: Physica Verlag. 
Jensen, J. M. (2012). Shopping orientation and online travel shopping: The role of travel experience. International Journal of Tourism Research, 14(1), 56-70.

Jeong, M., \& Choi, J. (2005). Effects of picture presentations on customers' behavioral intentions on the web. Journal of Travel \& Tourism Marketing, 17(2), 193-204.

Jun, S. H., Vogt, C. A., \& MacKay, K. J. (2007). Relationships between travel information search and travel product purchase in pretrip contexts. Journal of Travel Research, 45(3), 266-274.

Kah, J. A., Vogt, C., \& Mackay, K. J. (2008). Online travel information search and purchasing by Internet use experiences. Information Technology \& Tourism, 10(3), 227-243.

Kamarulzaman, Y. (2007). Adoption of travel e-shopping in the UK. International Journal of Retail \& Distribution Management, 35(9), 703-719.

Kamarulzaman, Y. (2010). Geodemographics of travel eshoppers: An empirical analysis of UK consumers. European Journal of Social Sciences, 16(2), 195-205.

Kasavana, M. L., Nusair, K., \& Teodosic, K. (2010). Online social networking: Redefining the human web. Journal of Hospitality and Tourism Technology, 1(1), 68-82.

Khare, A., \& Khare, A. (2010). Travel and tourism industry yet to exploit the Internet fully in India. Journal of Database Marketing \& Customer Strategy Management, 17(2), 106-119.

Kim, D. J., Kim, W. G., \& Han, J. S. (2007). A perceptual mapping of online travel agencies and preference attributes. Tourism Management, 28(2), 591-603.

Kim, L. H., Kim, D. J., \& Leong, J. K. (2005). The effect of perceived risk on purchase intention in purchasing airline tickets online. Journal of Hospitality \& Leisure Marketing, 13(2), 33-53.

Kim, L. H., Qu, H., \& Kim, D. J. (2009). A study of perceived risk and risk reduction of purchasing air-tickets online. Journal of Travel \& Tourism Marketing, 26(3), 203-224.

Kim, S., \& Lee, Y. (2006). Global online marketplace: A cross-cultural comparison of website quality. International Journal of Consumer Studies, 30(6), 533-543.

Kim, W. G., \& Kim, D. J. (2004). Factors affecting online hotel reservation intention between online and nononline customers. International Journal of Hospitality Management, 23(4), 381-395.

Kim, W. G., Ma, X., \& Kim, D. J. (2006). Determinants of Chinese hotel customers' e-satisfaction and purchase intentions. Tourism Management, 27(5), 890-900.

Klein, S., Kohne, F., \& Oorni, A. (2004). Barriers to online booking of scheduled airline tickets. Journal of Travel \& Tourism Marketing, 17(2), 27-39.

Kolsaker, A., Lee-Kelley, L., \& Choy, P. C. (2004). The reluctant Hong Kong consumer: Purchasing travel online. International Journal of Consumer Studies, 28(3), 295-304.
Ku, E., \& Fan, Y. W. (2009). The decision making in selecting online travel agencies: An application of analytic hierarchy process. Journal of Travel \& Tourism Marketing, 26(5), 482-493.

Law, R. (2010). An analysis of the impact of tourism journals on Google Scholar. In U. Gretzel, R. Law, \& M. Fuchs (Eds.), Information and communication technologies in tourism 2010 (pp. 333-343). Vienna, Austria: Springer.

Law, R., \& Bai, B. (2008). How do the preferences of online buyers and browsers differ on the design and content of travel websites? International Journal of Contemporary Hospitality Management, 20(4), 388-400.

Law, R., Bai, B., \& Leung, B. (2008). Travel website uses and cultural influence: A comparison between American and Chinese travelers. Information Technology \& Tourism, 10(3), 215-225.

Law, R., Leung, K., \& Wong, J. (2004). The impact of the Internet on travel agencies. International Journal of Contemporary Hospitality Management, 16(2), 100-107.

Law, R., Qi, S., \& Buhalis, D. (2010). Progress in tourism management: A review of website evaluation in tourism research. Tourism Management, 31(3), 297-313.

Lee, H. Y., Qu, H., \& Kim, Y. S. (2007). A study of the impact of personal innovativeness on online travel shopping behavior-A case study of Korean travelers. Tourism Management, 28(3), 886-897.

Leggatt, H. (2011, March 2). Travel purchases top of online shopping lists in Asia. Retrieved from http:// www.bizreport.com/2011/03/travel-purchases-top-ofonline-shopping-lists-in-asia.html

Lewis, I., Semeijn, J., \& Talalayevsky, A. (1998). The impact of information technology on travel agents. Transportation Journal, 37(4), 20-25.

Lexhagen, M. (2005). The importance of value-added services to support the customer search and purchase process on travel websites. Information Technology \& Tourism, 7(2), 119-135.

Li, L., \& Buhalis, D. (2005). Predicting Internet usage for travel bookings in China. In A. J. Frew (Ed.), Information and communication technologies in tourism 2005 (pp. 429-439). Vienna, Austria: Springer.

Li, L., \& Buhalis, D. (2006). E-commerce in China: The case of travel. International Journal of Information Management, 26(2), 153-166.

Limayem, M., Khalifa, M., \& Frini, A. (2000). What makes consumers buy from Internet? A longitudinal study of online shopping. IEEE Transactions on Systems, Man, and Cybernetics-Part A: Systems and Humans, 30(4), 421-432.

Lin, H.-F. (2007). Predicting consumer intentions to shop online: An empirical test of competing theories. Electronic Commerce Research and Applications, 6(4), 433-442.

Lin, P.-J., Jones, E., \& Westwood, S. (2009). Perceived risk and risk-relievers in online travel purchase intentions. 
Journal of Hospitality Marketing \& Management, 18(8), 782-810.

Ma, J. E., \& Law, R. (2009). Components of tourism research: Evidence from Annals of Tourism Research. Anatolia: An International Journal of Tourism and Hospitality Research, 20(1), 62-74.

Marcussen, C. H. (1999). Internet distribution of European travel and tourism services. Bornholm, Denmark: Research Centre of Bornholm.

Mayr, T., \& Zins, A. H. (2009). Acceptance of online vs. traditional travel agencies. Anatolia: An International Journal of Tourism and Hospitality Research, 20(1), 164-177.

McCole, P. (2002). The role of trust for electronic commerce in services. International Journal of Contemporary Hospitality Management, 14(2), 81-87.

McKercher, B., Law, R., \& Lam, T. (2006). Rating tourism and hospitality journals. Tourism Management, 27(6), 1235-1252.

Microsoft. (1997, October 1). Microsoft Expedia travel service to be premier provider of active channel content for Microsoft Internet Explorer 4.0. Retrieved from http://www.microsoft.com/presspass/press/1997/ oct97/expchnpr.mspx

Mitra, S. (2007, April 27). Travelocity: Great content and even better commerce. Retrieved from http://www. readwriteweb.com/archives/travelocity_gre.php

Moital, M., Vaughan, R., \& Edwards, J. (2009). Using involvement for segmenting the adoption of e-commerce in travel. The Service Industries Journal, 29(5), 723-739.

Moital, M., Vaughan, R., Edwards, J., \& Peres, R. (2009). Determinants of intention to purchase over the Internet. Anatolia: An International Journal of Tourism and Hospitality Research, 20(2), 345-358.

Morosan, C., \& Jeong, M. (2006). Understanding travelers' adoption of hotel reservation web sites. In M. Hitz, M. Sigala, \& J. Murphy (Eds.), Information and communication technologies in tourism 2006 (pp. 394-405). Vienna, Austria: Springer.

Morosan, C., \& Jeong, M. (2008). Users' perceptions of two types of hotel reservation web sites. International Journal of Hospitality Management, 27(2), 284-292.

Morrison, A. M., Jing, S., O’Leary, J. T., \& Cai, L. A. (2001). Predicting usage of the Internet for travel bookings: An exploratory study. Information Technology \& Tourism, 4(1), 15-30.

Murphy, J., \& Law, R. (2008). Google Scholar visibility and tourism journals. Annals of Tourism Research, 35(4), 1078-1082.

Nielsen. (2008, January 28). Over 875 million consumers have shopped online-The number of Internet shoppers up $40 \%$ in two years. Retrieved from http:// www.nielsen.com/us/en/insights/press-room/2008/ over_875_million_consumers.html
O'Connor, P. (2008). User-generated content and travel: A case study on Tripadvisor.com. In P. O'Connor, W. Hopken, \& U. Gretzel (Eds.), Information and communication technologies in tourism 2008 (pp. 47-58). Vienna, Austria: Springer.

Park, J., \& Chung, H. (2009). Consumers' travel website transferring behaviour: Analysis using clickstream data-time, frequency, and spending. The Service Industries Journal, 29(10), 1451-1463.

Pavlou, P. A., \& Fygenson, M. (2006). Understanding and predicting electronic commerce adoption: An extension of the theory of planned behavior. Management Information Systems Quarterly, 30(1), 115-143.

Pechlaner, H., Zehrer, A., Matzler, K., \& Abfalter, D. (2004). A ranking of international tourism and hospitality journals. Journal of Travel Research, 42(4), 328-332.

PhoCusWright. (2011, July). PhoCusWright's social media in travel 2011: Traffic, activity and sentiment. Retrieved from http://www.phocuswright.com/ store/1669\#table_of_contents

Powley, J. H., Cobanoglu, C., \& Cummings, P. R. (2004). Determinants of online travel purchases from thirdparty travel web sites. In A. J. Frew (Ed.), Information and communication technologies in tourism 2004 (pp. 424-436). Vienna, Austria: Springer.

Rogers, E. M. (1995). Diffusion of innovations (4th ed.). New York, NY: The Free Press.

Rothschild, M. L. (1984). Perspectives on involvement: Current problems and future directions. Advances in Consumer Research, 11(1), 216-217.

Ryan, C. (2005). The ranking and rating of academics and journals in tourism research. Tourism Management, 26(5), 657-662.

Ryan, C., \& Rao, U. (2008). Holiday users of the InternetEase of use, functionality and novelty. International Journal of Tourism Research, 10(4), 329-339.

San Martín, H., \& Herrero, Á. (2012). Influence of the user's psychological factors on the online purchase intention in rural tourism: Integrating innovativeness to the UTAUT framework. Tourism Management, 33(2), 341-350.

Seglen, P. O. (1997). Why the impact factor of journals should not be used for evaluating research. $B M J$, 314(7079), 497.

Shao, J., \& Gretzel, U. (2010). Looking does not automatically lead to booking: Analysis of clickstreams on a Chinese travel agency website. In U. Gretzel, R. Law, \& M. Fuchs (Eds.), Information and communication technologies in tourism 2010 (pp. 197-208). Vienna, Austria: Springer.

SITA. (2008). Airline IT trends survey 2008. Retrieved from http://www.sita.aero/content/airline-it-trendssurvey-2008

Susskind, A. M., \& Stefanone, M. A. (2010). Internet apprehensiveness: An examination of on-line 
information seeking and purchasing behavior. Journal of Hospitality and Tourism Technology, 1(1), 5-29.

Susskind, A. M., Bonn, M. A., \& Dev, C. S. (2003). To look or book: An examination of consumers' apprehensiveness toward Internet use. Journal of Travel Research, 41(3), 256-264.

Taylor, S., \& Todd, P. A. (1995). Understanding information technology usage: A test of competing models. Information Systems Research, 6(2), 144-176.

Travel Pulse. (2011, April 21). PhoCusWright predicts one in three travelers will book online. Retrieved from http://www.travelpulse.com/phocuswright-predictsone-in-three-travelers-will-book-online.html

Vijayasarathy, L. R. (2004). Predicting consumer intentions to use on-line shopping: The case for an augmented technology acceptance model. Information \& Management, 41(6), 747-762.

Weber, K., \& Roehl, W. S. (1999). Profiling people searching for and purchasing travel products on the World Wide Web. Journal of Travel Research, 37(3), 291-298.

Webster, J., \& Watson, R. T. (2002). Analyzing the past to prepare for the future: Writing a literature review. MIS Quarterly, 26(2), xiii-xxiii.

Wen, I. (2010). Online travelers' decision makings: A new equation model to evaluate impacts of website, search intention, and trust. Information Technology \& Tourism, 12(2), 153-173.

Werthner, H., \& Klein, S. (1999). Information technology and tourism-A challenging relationship. Vienna, Austria: Springer.

Wolfe, K., Hsu, C., \& Kang, S. (2004). Buyer characteristics among users of various travel intermediaries. Journal of Travel \& Tourism Marketing, 17(2), 51-62.

Wong, J., \& Law, R. (2005). Analysing the intention to purchase on hotel websites: A study of travellers to Hong Kong. International Journal of Hospitality Management, 24(3), 311-329.
Xiang, Z., \& Gretzel, U. (2010). Role of social media in online travel information search. Tourism Management, 31(2), 179-188.

SUBMITTED: May 15, 2012 FIRST REVISION SUBMITTED:

October 4, 2012

ACCEPTED: October 25, 2012 REFEREED ANONYMOUSLY

\section{APPENDIX}

\section{Selected Journals and Conference Proceedings Included in the Literature Review}

Journals and Proceedings (in alphabetic order)

Annals of Tourism Research

Asia Pacific Journal of Tourism Research

Cornell Quarterly

International Journal of Contemporary Hospitality

Management

International Journal of Hospitality Management

International Journal of Tourism Research

Journal of Hospitality and Tourism Technology

Journal of Information Technology \& Tourism

Journal of Sustainable Tourism

Journal of Leisure Research

Journal of Tourism Studies

Journal of Travel and Tourism Marketing

Journal of Travel Research

Information and Communication Technologies in Tourism

Tourism Analysis

Tourism Economics

Tourism Management 